\title{
Hydrogeology of an Alpine rockfall aquifer system and its role in flood attenuation and maintaining baseflow
}

\author{
U. Lauber ${ }^{1}$, P. Kotyla ${ }^{2}$, D. Morche ${ }^{3}$, and N. Goldscheider ${ }^{1}$ \\ ${ }^{1}$ Institute of Applied Geosciences, Division of Hydrogeology, Karlsruhe Institute of Technology (KIT), Kaiserstr. 12, \\ 76131 Karlsruhe, Germany \\ ${ }^{2}$ Chair of Hydrogeology, Technische Universität München (TUM), Arcisstr. 21, 80333 Munich, Germany \\ ${ }^{3}$ Institute for Geosciences and Geography, Martin-Luther-University, 06099 Halle, Germany \\ Correspondence to: U. Lauber (ute.lauber@kit.edu) and N. Goldscheider (goldscheider@kit.edu)
}

Received: 5 May 2014 - Published in Hydrol. Earth Syst. Sci. Discuss.: 25 June 2014

Revised: 5 September 2014 - Accepted: 28 September 2014 - Published: 6 November 2014

\begin{abstract}
The frequency and intensity of extreme hydrological events in Alpine regions is projected to increase with climate change. The goal of this study is to better understand the functioning of aquifers composed of complex alluvial and rockfall deposits in Alpine valleys and to quantify the role of these natural storage spaces in flood attenuation and baseflow maintenance. Geomorphological and hydrogeological mapping, tracer tests, and continuous flow measurements were conducted in the Reintal (German Alps), where runoff from a karst spring infiltrates a series of postglacial alluvial/rockfall aquifers. During high-flow conditions, groundwater velocities of $30 \mathrm{~m} \mathrm{~h}^{-1}$ were determined along $500 \mathrm{~m}$; hydrograph analyses revealed short lag times $(5 \mathrm{~h})$ between discharge peaks upstream and downstream from the aquifer series; the maximum discharge ratio downstream (22) and the peak recession coefficient $\left(0.196 \mathrm{~d}^{-1}\right)$ are low compared with other Alpine catchments. During low-flow conditions, the underground flow path length increased to $2 \mathrm{~km}$ and groundwater velocities decreased to $13 \mathrm{~m} \mathrm{~h}^{-1}$. Downstream hydrographs revealed a delayed discharge response after $101 \mathrm{~h}$ and peaks damped by a factor of 1.5 . These results indicate that alluvial/rockfall aquifers might play an important role in the flow regime and attenuation of floods in Alpine regions.
\end{abstract}

\section{Introduction}

Snowmelt is a major hydrologic component of flow regimes in Alpine regions; these regimes therefore are particularly sensitive to climate change (Barnett et al., 2005). The temperature in the Alps has increased $2{ }^{\circ} \mathrm{C}$ since 1901 , which is twice the average warming of the Northern Hemisphere (Auer et al., 2007). A shift of snow and precipitation patterns accompanied by higher precipitation in winter and poor snow storage are likely to substantially affect the timing and magnitude of summer discharge. Extreme events, such as floods and droughts, are expected to increase in frequency and intensity/magnitude (Bogataj, 2007). Because of the high contribution of Alpine runoff to the total discharge of major streams in Europe, climate change will affect hydrology at lower elevations as well as in Alpine regions.

The assessment of potential effects of climate change on Alpine water resources requires an understanding of recharge and drainage processes. The geological and lithological setting is often complex and has major influence on recharge, storage, and discharge processes (Gremaud et al., 2009; Goldscheider and Neukum, 2010). A thorough knowledge of the geologic framework and a conceptual model of the recharge area provide the basis for characterizing Alpine groundwater systems (Plan et al., 2009). To assess underground drainage properties in high-elevated catchments, hydrochemical classification and spring monitoring methods are applied. Such methods allow the characterization of flow components and spring responses to precipitation events so that transit times can be estimated and the presence of preferential flow paths determined (Maloszewski et al., 2002; Wetzel, 2004; Mueller et al., 2013). Artificial tracer tests enable the determination of flow velocities, water volumes, and storage capacities within the Alpine aquifer (Goldscheider, 2005; Gremaud et al., 2009; Finger et al., 2013). These parameters control the amount of quickflow and baseflow, and 
thus have a large influence on flood generation and baseflow maintenance.

To investigate discharge properties in Alpine headwaters, spring hydrograph studies have been conducted. It has been demonstrated that soil and vegetation (Badoux et al.. 2006), topography (Merz and Blöschl, 2009) and subsurface flow components (Zillgens et al., 2007) have major control over discharge response in individual headwater catchments. Discharge properties often used include the discharge response (the ratio between peak discharge and maximum precipitation intensity), the unit conversion factor, and the catchment area (Blume et al., 2007). Furthermore, the discharge ratio, defined here as the ratio between peak discharge and initial discharge, and the time lag between precipitation and the discharge peak at springs and streams are considered (Haga et al., 2005). Stormflow and baseflow recession characteristics can further help to characterize fast and slow discharge components (Millares et al., 2009). The presence of low permeability bedrock, sparse vegetation, and high topographic gradients are likely to cause large amounts of surface runoff, which leads to high peak discharge of Alpine streams and rapid stormflow recession (Wetzel, 2003). However, a steady amount of base flow, indicated by low baseflow recession, is particularly important for baseflow maintenance in dry periods and depends greatly on the geologic structure of the aquifer, e.g., the presence of permeable structures, a high effective porosity, or triple porosity such as occur in karst aquifers (Geyer et al., 2008). A detailed understanding of hydrogeological settings and discharge properties is necessary to construct vulnerability maps of Alpine regions, which are particularly affected by floods and droughts. For maintaining and protecting natural retention zones and for developing water management strategies, natural groundwater reservoirs in the Alps need to be understood. Furthermore, the feasibility of engineering works, e.g., dams, river channels, large-scale irrigation schemes, and energy production projects, is determined on the basis of the hydrogeological data. Such knowledge is required for effective flood management and the increase of water storage capacity (Viviroli and Weingartner, 2008; Beniston et al., 2011).

Although there is a need to investigate the hydrogeology of Alpine aquifers and their drainage systems, information remains incomplete because of the poor accessibility of Alpine areas and the great effort required to obtain data. Only about $3 \%$ of the publications in hydrogeologic journals are related to alpine topics (Goldscheider, 2011) and most of those studies focus on fractured and karstic aquifers, e.g., the studies cited above. Few studies deal with the hydrogeology of alpine alluvial/rockfall aquifers, which are frequently found in steep, high alpine valleys (Sinreich et al., 2002; Wassmer et al., 2004; Bichler et al., 2012). Because of the strong interaction between surface flow and subsurface drainage, alluvial/rockfall deposits are likely to influence the discharge pattern of the alpine catchment area. This might be especially important in karst catchments, where concentrated and rapid drainage through karst conduits results in large variability in discharge. To investigate this aspect and to contribute to a better understanding of Alpine aquifers, this study focuses on the hydrogeology of a rockfall aquifer system in the Reintal (Wetterstein mountains, Germany). Detailed geomorphologic investigations of the sedimentary filling of the Reintal (Hoffmann and Schrott, 2003; Schrott et al., 2006; Morche et al., 2007, 2008; Sass et al., 2007) provided the basis for this hydrogeological research, which includes a combination of tracer tests and hydrograph analyses.

The study had five major goals. The initial assessment of the catchment area involves (1) the development of a conceptual model and the identification of discharge components and (2) the characterization of discharge patterns under different flow conditions. A second step involves (3) the determination of drainage parameters of the alluvial/rockfall aquifer and (4) the quantification of discharge characteristics of the system. The final goal of the study was (5) the evaluation of effects on flood buffering and baseflow maintenance of the alluvial/rockfall aquifer system.

\section{Field site}

\subsection{Geographical and geological setting}

The Wetterstein mountains are located in the Bavarian Alps near the border between Germany and Austria (Fig. 1). They consist of three mountain ridges that form some of the highest summits in Germany, including the Zugspitze (2962 m a.s.1.). The deeply incised Reintal has steep mountain slopes and a topographic relief of up to $2000 \mathrm{~m}$ between the valley floor and the summits. Above $2000 \mathrm{~m}$ a.s.1., vegetation is sparse and bare rocks dominate the landscape. The Zugspitzplatt cirque is still partially covered by vestigial glaciers with a total extent of about 32.6 ha (in 2009).

The geological and lithological setting of the Wetterstein mountains is dominated by Triassic Wetterstein limestone, which is as much as $1000 \mathrm{~m}$ thick and forms the main karst aquifer (Fig. 2). The underlying strata are comprised of a sequence of marl and well-bedded limestone, the Partnach and Alpine Muschelkalk formations. The folded strata form two large synclines and one anticline, which appear as valleys and ridges. The fold axes trend $\mathrm{W}-\mathrm{E}$ and plunge to the east $\left(20-35^{\circ}\right)$.

Since the Eocene, much of the region has been uplifted almost steadily to a high mountain massif. The exposure of the limestone established the basis for karstification and intense weathering, including gravitational erosion. Karstification is particularly high at the cirques, where topographic gradients are lower and underground drainage dominates. Thus, a welldeveloped karst conduit system is present at the Zugspitzplatt cirque. In contrast, only small surface karst structures, such as karren, are developed along steep mountain ridges as 


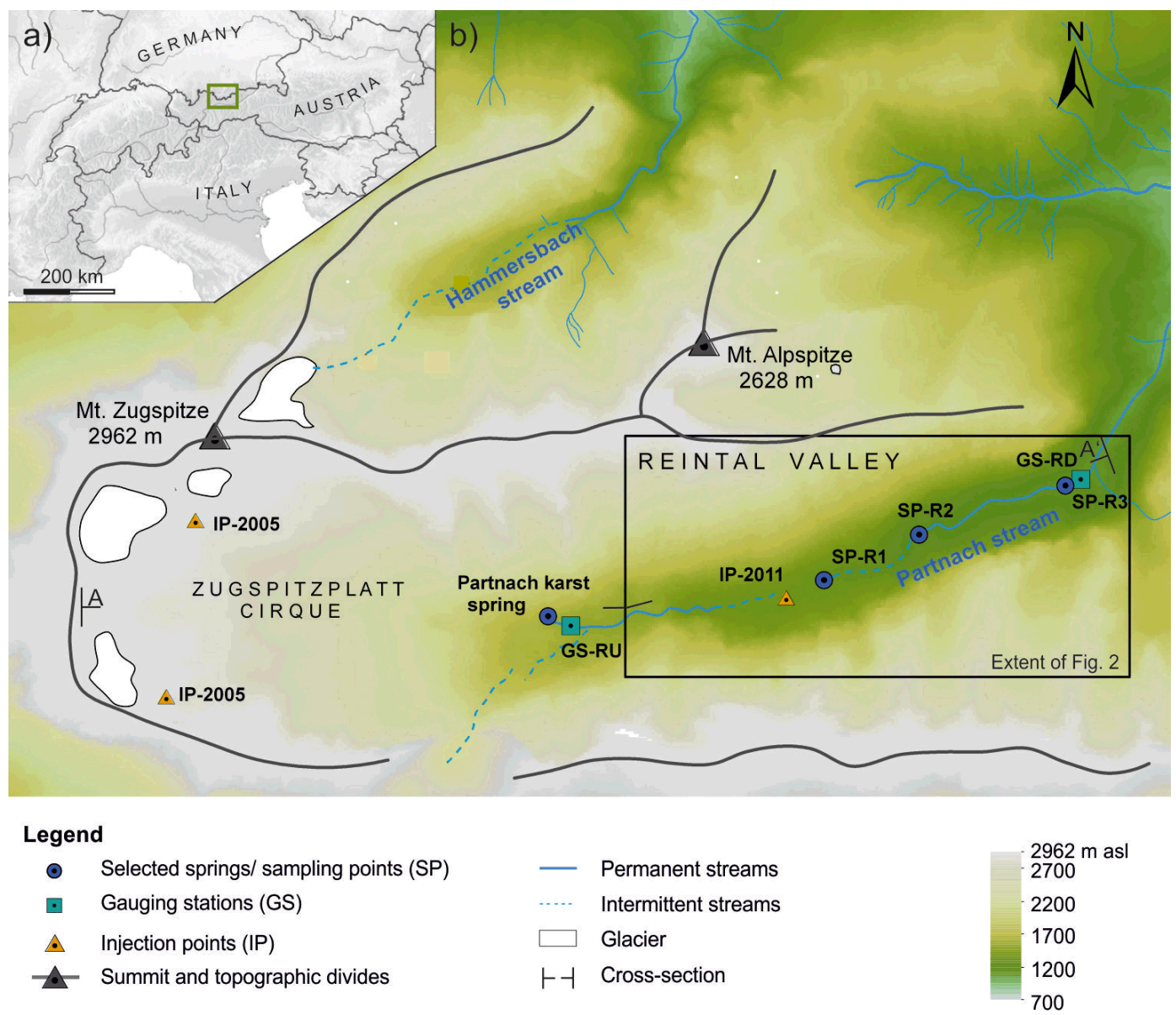

Figure 1. (a) Map of the study site (Wetterstein mountains) in the German Alps; (b) Wetterstein mountains, including Germany's highest summit (the Zugspitze), the large Zugspitzplatt cirque, and the high alpine Reintal extending to the east. Tracer injections at the Zugspitzplatt cirque (IP-2005) were conducted by Rappl et al. (2010); IP-2011 is part of this study. GS-RU and GS-RD are gauging stations in the Reintal, upstream (RU) and downstream (RD) from the alluvial/rockfall aquifers. The area in the rectangle is shown in detail in Fig. 2 . A detail of the cross-section A-A' is provided in Fig. 4.

gravitational erosion and frost wedging occur along numerous fissures and fractures.

During the glaciation in the Quaternary Period, strong glacial erosion caused the present shape of the valleys, including sequences of cirques. After the retreat of glaciers and the melting of permafrost, several rockslides occurred during the Holocene along the steepened Alpine valley slopes (Haeberli and Beniston, 1998). Two major rockslides occurred about 200 and 500 years ago in the Reintal (Schmidt and Morche, 2006). Mountain lakes formed upstream of the natural rockfall dams, but were gradually filled by sediment. The last remnant of the lower lake disappeared during a highflow event with associated sedimentation in 2005 (Fig. 3). The alluvial plains and rockfall deposits thus have created a series of two alluvial/rockfall aquifers about $2 \mathrm{~km}$ long down the valley (Figs. 2 and 4 ). The Quaternary sediments are comprised of talus sheets and cones, debris cones, rockfall deposits, alluvial fans, avalanche deposits, moraines, and fluvial gravel (Schrott et al., 2006) (Fig. 2).

As a result of gravitational mass movement, the grain-size spectrum of the rockfall deposits, talus sheets, and cones covers a wide range, including large blocks with edge lengths of several meters. The coarse-grained sediments consist mainly of Wetterstein limestone, and the unsorted components form well-drained parts of the alluvial/rockfall aquifer system (Fig. 2).

The alluvial plains consist of fluvial gravel, transported by the Alpine stream and surface runoff from steep slopes along the valley. Because of the reduced flow velocity and transport force, the gravel was deposited behind the rockfall dams (Morche and Schmidt, 2005). The sediments contain coarsegrained delta sediments and fine limnic sediments developed in proximity to the rockfall deposits. At the surface of the alluvial plain, braided river systems have developed whose locations shift following flood events. The unconsolidated 


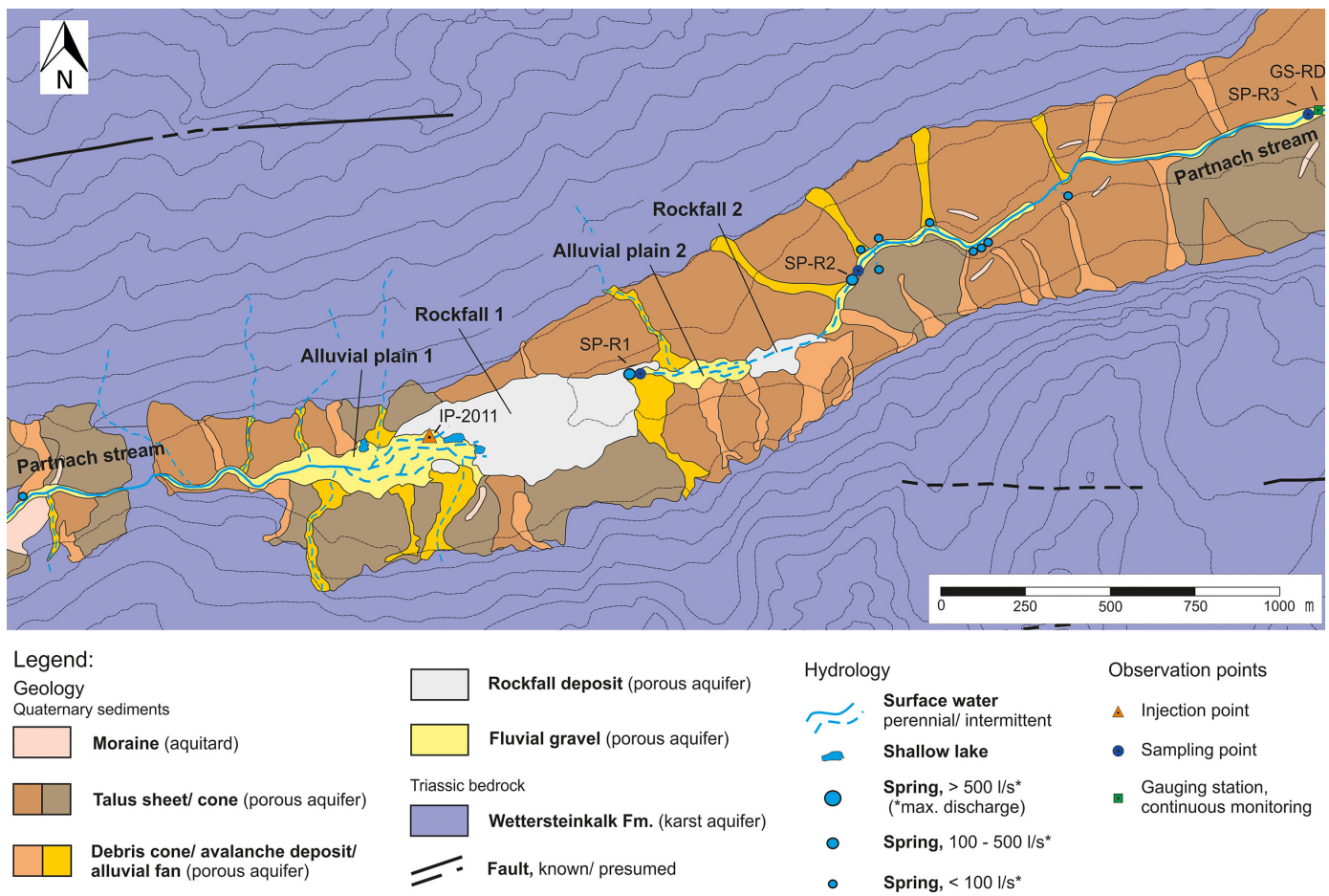

Figure 2. Hydrogeologic map of the Reintal covered with postglacial sediments, including alluvial plains and rockfall deposits (Schrott et al., 2006). The occurrence and location of surface streams and springs depends on hydrologic conditions. A longitudinal profile is provided in Fig. 4.

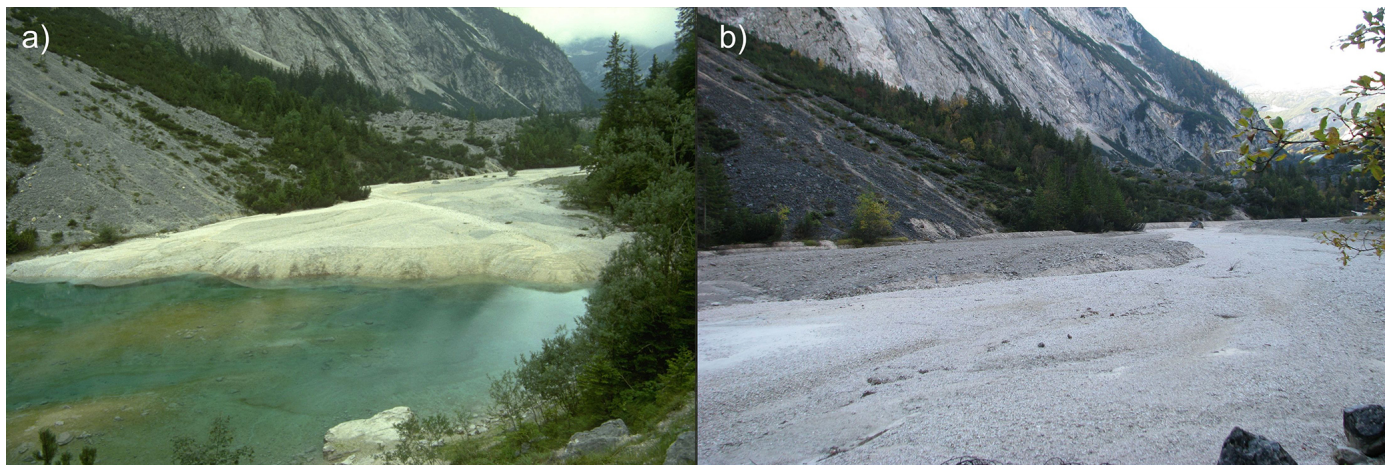

Figure 3. View of the second alluvial plain: (a) an ephemeral mountain lake created by a natural rockfall dam; (b) the same area filled with sediment after a high precipitation event in 2005.

alluvial deposits are part of the well-drained alluvial/rockfall aquifer, and surface streams infiltrate as a result of the high permeability.

\subsection{Hydrologic and hydrogeologic setting}

The headwater in the Reintal, the Partnach stream, forms a tributary of the Loisach River north of the Wetterstein mountains (Fig. 1). Discharge is comprised of meltwater from the glaciers, snow, and precipitation. Glacial and snow meltwater contribute about $30 \%$ of the annual spring discharge (Wetzel, 2004).
In the upper valley, the stream is fed mainly by the Partnach spring (Fig. 1). With a mean discharge of $1.2 \mathrm{~m}^{3} \mathrm{~s}^{-1}$ between May and November (2005-2011) and a recorded maximum discharge of $17 \mathrm{~m}^{3} \mathrm{~s}^{-1}$ (2005, Morche et al., 2007), this karst spring is among the largest in the German Alps. The large discharge variability of the karst spring indicates that a well-developed karst conduit system exists in the catchment area. In the lower valley, the hydrology is largely controlled by the Quaternary deposits at the bottom of the valley (Fig. 2). As surface water crosses the alluvial plains, it infiltrates the alluvial sediments and rockfall deposits. Downstream from each alluvial/rockfall deposit is a spring that 


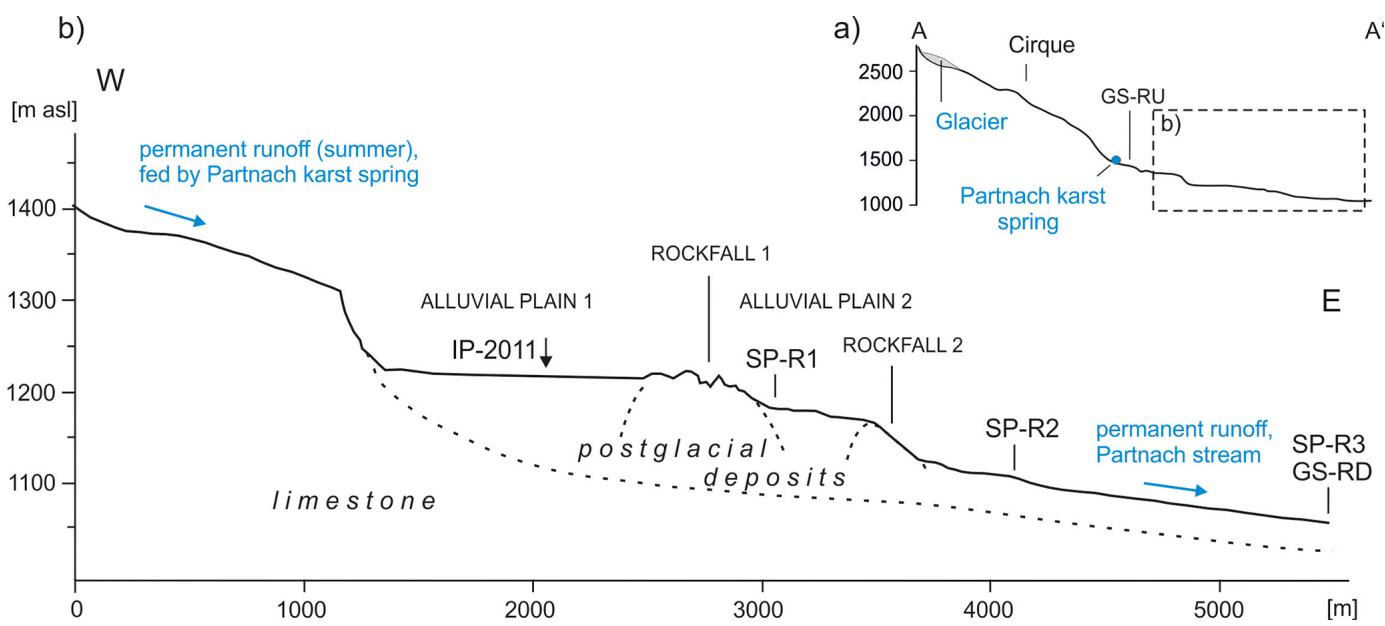

Figure 4. (a) Overview over the Reintal indicating the major hydrologic inflow from the glacier and the karst spring. (b) Schematic diagram of the alluvial/rockfall aquifer system in the Reintal. Although perennial flow exists upstream and downstream, several sinks and springs between the alluvial/rockfall deposits result in intermittent discharge. Cross sections are vertically exaggerated.

drains the alluvial/rockfall aquifer system: one spring is intermittent (SP-R1) and one is perennial (SP-R2) (Fig. 4). The spring SP-R2 is located in the river bed and its discharge immediately mixes with surface flow if the river is flowing. Several more springs discharge from the river bed downstream from the rockfall deposits. The presence of these springs is attributed to the decrease in the thickness of the Quaternary deposits and the narrowing of the river bed. As a result, stream discharge increases substantially in this part of the valley. The total discharge from the Reintal is measured at the downstream end of the valley (gauging station GS-RD, Fig. 1). The sampling point SP-R3 is located at the gauging station and samples groundwater from the alluvial/rockfall deposits and surface runoff. The mean annual discharge associated with the $28 \mathrm{~km}^{2}$ catchment area during 2005-2011 is about $1.8 \mathrm{~m}^{3} \mathrm{~s}^{-1}$.

\section{Methods}

\subsection{Artificial tracer tests}

To investigate the alluvial/rockfall aquifer system in the valley, a tracer test with $5 \mathrm{~kg}$ of the fluorescent dye sodium naphthionate (CAS 130-13-2) was conducted on 19 July 2011. The injection was performed after several days of rain, which resulted in high discharge at all springs in the valley. Where the stream flows through the upper alluvial plain, it forms a braided river system that completely infiltrates the coarsegrained alluvial/rockfall deposits at several swallow holes (Fig. 2). The tracer was injected into one of the numerous swallow holes near the lower end of the alluvial plain, where the infiltration rate into the rockfall deposits was about $6 \mathrm{~L} \mathrm{~s}^{-1}$. The dye was dissolved in a $20 \mathrm{~L}$ canister at the injection site and the tracer solution was injected instantaneously.
Observation points were located downstream in the valley: at the springs draining the alluvial/rockfall masses (SP-R1 and SP-R2) and further downstream at the outlet of the valley (SP-R3) (Fig. 4). Although the samples collected at SP$\mathrm{R} 1$ represent groundwater discharge at the spring, samples collected at SP-R2 and SP-R3 also contain surface water. Groundwater discharge from spring SP-R2 could only be sampled under low-flow conditions, when the river bed was dry. If the river was flowing, samples from this sampling station were a mixture of spring water and surface runoff. At SP-R3, a mixture of groundwater and surface water was sampled in the stream which enables calculation tracer recovery from the whole aquifer system. At the spring closest to the injection point (SP-R1), water samples were collected every $30 \mathrm{~min}$ during the first $10 \mathrm{~h}$ following tracer injection. In the following days, as many as six water samples were collected per day. The final samples were collected 3 weeks after injection.

Two fluorescence spectrometers (PerkinElmer, LS 50 B and LS 55) in the hydrogeology laboratory of the Karlsruhe Institute of Technology were used to measure tracer concentration in water samples, using the synchronous scan method. Tracer recovery was calculated using discharge data from springs and gauging stations.

\subsection{Discharge measurements}

The two principal gauging stations in the valley are located at the Partnach karst spring upstream from the alluvial/rockfall deposits (site GS-RU) and at the outlet of the alluvial/rockfall aquifer system (site GS-RD) (Fig. 1). Water levels were measured every 15 min during observation periods with data loggers DL 8.4 (EBRU), Orphimedes, and Orpheus K (Ott Hydrometrie) (Schmidt and Morche, 2006). Measurements were collected from late spring until late autumn, as snow, 
ice, and avalanches inhibit measurement in the winter season. Data from 2002-2011 were evaluated, but no measurements were conducted at GS-RU in 2009. Discharge was measured using a current meter (Ott C2) for a range of flow conditions. At other observation points in the valley, e.g., SP-R1 and SP-R2, discharge was measured manually by the salt dilution method. Using the dilution technique, sodium chloride was added to the discharge, and the electrical conductivity, i.e., the dilution, was measured downstream, enabling calculation of the discharge (Leibundgut et al., 2009).

\subsection{Data analysis}

All breakthrough curves (BTCs) from the tracer tests were analyzed quantitatively. The time of first detection $\left(t_{0}\right)$, maximum flow velocity $\left(v_{\max }\right)$, peak transit time $\left(t_{\text {peak }}\right)$, and peak flow velocity $\left(v_{\text {peak }}\right)$ were directly determined from the BTCs. Mean flow velocities $(v)$ and dispersion coefficients $(D)$ were quantified using the analytical advectiondispersion model (ADM) implemented in the CXTFIT software (Toride et al., 1999) (Eq. 1).

$\frac{\delta c}{\delta t}=D \frac{\delta^{2} c}{\delta x^{2}}-v \frac{\delta c}{\delta x}$

The model calculates one-dimensional flow of the tracer indicated by its concentration $(c)$ at a given distance $(x)$ in the direction of flow. The analytical equation is solved by assuming homogeneous flow profiles, a uniform and unidirectional flow field that is constant in time and space, and constant flow parameters (Van Genuchten et al., 2012). An inverse modeling tool of the ADM provides best estimates of the two flow parameters $(v, D)$ by fitting a modeled BTC to measured values.

Using additional information from discharge measurements, recovery was calculated according to Käss (2004). Water volume $(V)$ was estimated by multiplying the mean discharge $\left(Q_{\text {mean }}\right)$ and the mean transit time of the tracer ( $\left.t_{\text {mean }}\right)$ (Field and Nash, 1997).

In analyzing hydrographs, the best correlation of water level $(h)$ and discharge $(Q)$ is determined by fitting an exponential regression function with the two adjusting variables $a$ and $b$ (Eq. 2):

$Q=a \cdot e^{b h}$.

Coefficients of determination are greater than 0.72 and the standard error is smaller than 0.41 (Table S1 in the Supplement). To compare discharge characteristics from upstream and downstream of the series of alluvial/rockfall aquifers, hydrographs of the years 2006 and 2011 are presented in this paper as they have the most continuous records. The year 2006 is further characterized by extreme flow conditions. Annual discharge of the catchment is lowest of all observed years and an extreme precipitation event causes extreme high-flow conditions in August. Monthly mean discharge values of 2002 to 2011 are provided in Table S2.
Discharge was analyzed for all precipitation events that caused clear discharge peaks at the gauging stations. Rainfall events that occurred under very unstable discharge conditions, i.e., discharge fluctuations caused by snowmelt or long-lasting rainfall events, could not be analyzed because the occurrence of diffuse discharge peaks made it impossible to select related input and output signals properly. Precipitation data with a sampling interval of $6 \mathrm{~h}$ were obtained by Deutscher Wetterdienst (DWD) at the summit of the Zugspitze. As a consequence, the lag time between peak rainfall and peak discharge cannot be quantified at a higher resolution than $6 \mathrm{~h}$. Initial discharge for an event $\left(Q_{\mathrm{i}}\right)$ is defined as the discharge rate before the increase began, and peak discharge $\left(Q_{\mathrm{P}}\right)$ is defined as the discharge maximum. The discharge response $\left(Q_{\mathrm{P}} /\left(P_{\text {peak }} \cdot f_{\mathrm{c}} \cdot A\right)\right)$ is calculated by dividing the amount of peak discharge $\left(Q_{\mathrm{P}}\right.$, in $\left.\mathrm{m}^{3} \mathrm{~s}^{-1}\right)$ by the maximum precipitation intensity $\left(P_{\text {peak }}\right.$, in $\left.\mathrm{mm} \mathrm{h}^{-1}\right)$, a unit conversion factor $\left(f_{\mathrm{c}}\right)$ that converts discharge units from $\mathrm{m}^{3} \mathrm{~s}^{-1}$ to $\mathrm{mm} 6 \mathrm{~h}^{-1}$, and the catchment area $\left(A\right.$, in $\left.\mathrm{km}^{2}\right)$ (Blume et al., 2007). The increase of discharge after a precipitation event is described by the discharge ratio $Q_{\mathrm{P}} / Q_{\mathrm{i}}$. Additionally, the lag time between discharge peaks upstream (site GS-RU) and at the outlet of the catchment (site GSRD) was determined to assess discharge characteristics of the aquifer system.

Discharge response characteristics were described quantitatively by transfer functions (Asmuth and Knotters, 2004). This method can be applied to input signals that are transferred through a system and that result in distinctive output signals dispersed in time. In this case, the transferred signal can be described by an impulse-response function with a lognormal distribution (Eq. 3) (Long and Mahler, 2013).

$Q_{t}=Q_{\mathrm{i}}+\frac{A_{\mathrm{out}}}{t \omega \sqrt{2 \pi}} e^{-\frac{\left[\ln \frac{t}{t_{\mathrm{m}}}\right]^{2}}{2 \omega^{2}}}$,

where $A_{\text {out }}$ is a scaling coefficient that quantifies the area under the curve and $t_{\mathrm{m}}$ and $\omega$ describe mean transit time and its variance. In this study, discharge peak upstream from the alluvial/rockfall aquifer system (GS-RU) was used as the input impulse $(t=0)$. The output signal downstream from the alluvial/rockfall deposits (GS-RD) occurring at time $t$ after the input impulse was fitted with the function $\left(Q_{t}\right.$, Eq. 3). Because of additional surface runoff from steep slopes that occurs under mean- to high-flow conditions can interfere with the original input signal, only selected discharge responses under low-flow conditions with one clear input and one clear output signal were analyzed.

To quantify aquifer properties under stormflow and baseflow conditions, recession coefficients $(\alpha)$ were determined from hydrographs upstream (karst drainage) and downstream from the alluvial/rockfall aquifers. The falling limb of the hydrographs represents the drainage of groundwater reservoirs that exhibit distinct exponential flow rates for each groundwater reservoir (Bonacci, 1993; Bailly-Comte et al., 2010). 


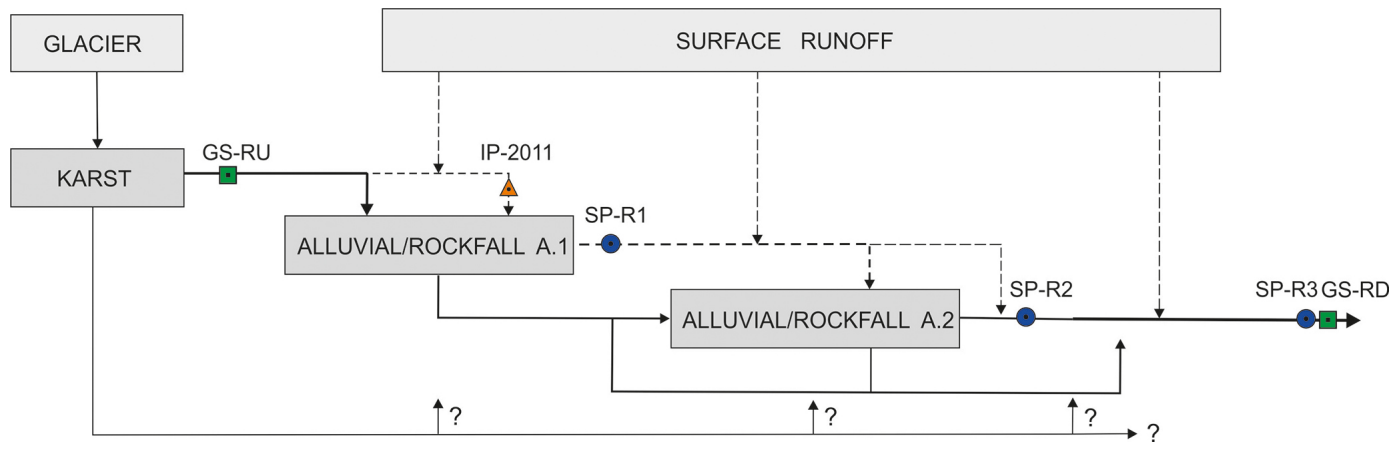

Figure 5. Conceptual model of the series of Alpine aquifers in the Reintal, which consists of a karst system and two alluvial/rockfall aquifer systems (i.e., alluvial/rockfall A.1 and A.2). Dashed lines indicate ephemeral discharge, solid lines indicate perennial discharge.

Recession curve analyses were done using an exponential function (Eq. 4):

$Q_{t}=Q_{0} \cdot e^{-\alpha t}$

where $Q_{0}$ is the initial spring discharge and $t$ is the time step following the decline of spring discharge $\left(Q_{t}\right)$. The recession curve was fitted separately for stormflow and baseflow sections of the hydrograph to obtain the recession coefficient $\alpha$. Because of the strong linear correlation on a semilogarithmic plot $\left(R^{2}>0.9\right)$, the use of Eq. (4) was justified (Zillgens et al., 2007).

\section{Results and discussions}

\subsection{Conceptual model}

The conceptual model of the Alpine valley consists of one karst aquifer and a series of two alluvial/rockfall aquifers. In the upper valley, the karst spring is the principal contributor to stream discharge (Fig. 5). All meltwater from glacial ice, snowmelt, and all precipitation in the highly karstified cirque drain through subsurface flow paths to the Partnach karst spring. Tracer tests have shown fast drainage along well-developed karst conduits with linear mean flow velocities of up to $104 \mathrm{~m} \mathrm{~h}^{-1}$ (Rappl et al., 2010). The lower valley is comprised of a series of two alluvial/rockfall aquifers (Fig. 5), each consisting of an alluvial plain and a rockfall deposit. The alluvial/rockfall aquifers are linked and characterized by a substantial thickness of postglacial sediments. All discharge from the karst spring infiltrates the first alluvial/rockfall aquifer because of the high permeability of the rockfall deposits (Fig. 6). Several sinks and sources, including SP-R1 and SP-R2, are located in the area of the aquifers; the number and location depend on flow conditions and water levels. Total discharge increases towards the outlet of the alluvial/rockfall system because of the decreasing thickness of the Quaternary fill and groundwater discharge into the surface stream. Hydraulic connections between the karst system and the alluvial/rockfall aquifer along the valley are of minor hydrologic importance (Fig. 6). Infiltration from the alluvial/rockfall aquifer into the karst aquifer can be excluded as discharge downstream from the alluvial/rockfall deposits (site GS-RD) is larger than at the upstream at site GS-RU. In contrast, Sinreich et al. (2002) demonstrated that the alluvial/rockfall aquifer in the Schwarzwasser valley (Austrian Alps) is drained by the underlying karst aquifer because of a well-developed karst drainage network. In the Reintal, a rapid glacial deepening of the valley inhibited the karstification of the limestone below the valley floor.

Here we define low-flow conditions as those under which all discharge from the Partnach karst spring infiltrates the alluvial/rockfall aquifer and follows a $2 \mathrm{~km}$ long subsurface flow path until it discharges at SP-R2 at the lower end of the alluvial/rockfall aquifer system (Fig. 6). Low-discharge conditions generally occur when baseflow is less than $0.8 \mathrm{~m}^{3} \mathrm{~s}^{-1}$ at site GS-RU and $1.8 \mathrm{~m}^{3} \mathrm{~s}^{-1}$ at site GS-RD. Peak discharge after precipitation events at GS-RU rarely exceeds $2.3 \mathrm{~m}^{3} \mathrm{~s}^{-1}$. Because the water table is low, there is no flow from spring SP-R1. At low water levels, spring SP-R2 is situated in the river bed as much as $600 \mathrm{~m}$ downstream from the alluvial/rockfall deposits (Morche et al., 2007) (Fig. 6). There is no surface runoff from steep slopes of the valley. Low-flow conditions generally occur in late summer, autumn, and winter, when there is little precipitation and no meltwater.

Moderate-flow conditions are characterized mainly as a transition between low and high flow and therefore often occur only for a short period of a few hours to a few days. Because the water table is higher than during low-flow conditions, part of the water discharges directly downstream from the first alluvial/rockfall deposits at spring SP-R1 after traveling along a short subsurface flow path of about $500 \mathrm{~m}$ (Fig. 6). Until 2005, there was a small ephemeral mountain lake on the second alluvial plain, which functioned as a water reservoir and sediment trap (Schmidt and Morche, 2006) (Fig. 3). Today, discharge from SP-R1 infiltrates the second alluvial/rockfall aquifer after traveling along a short surface 
W
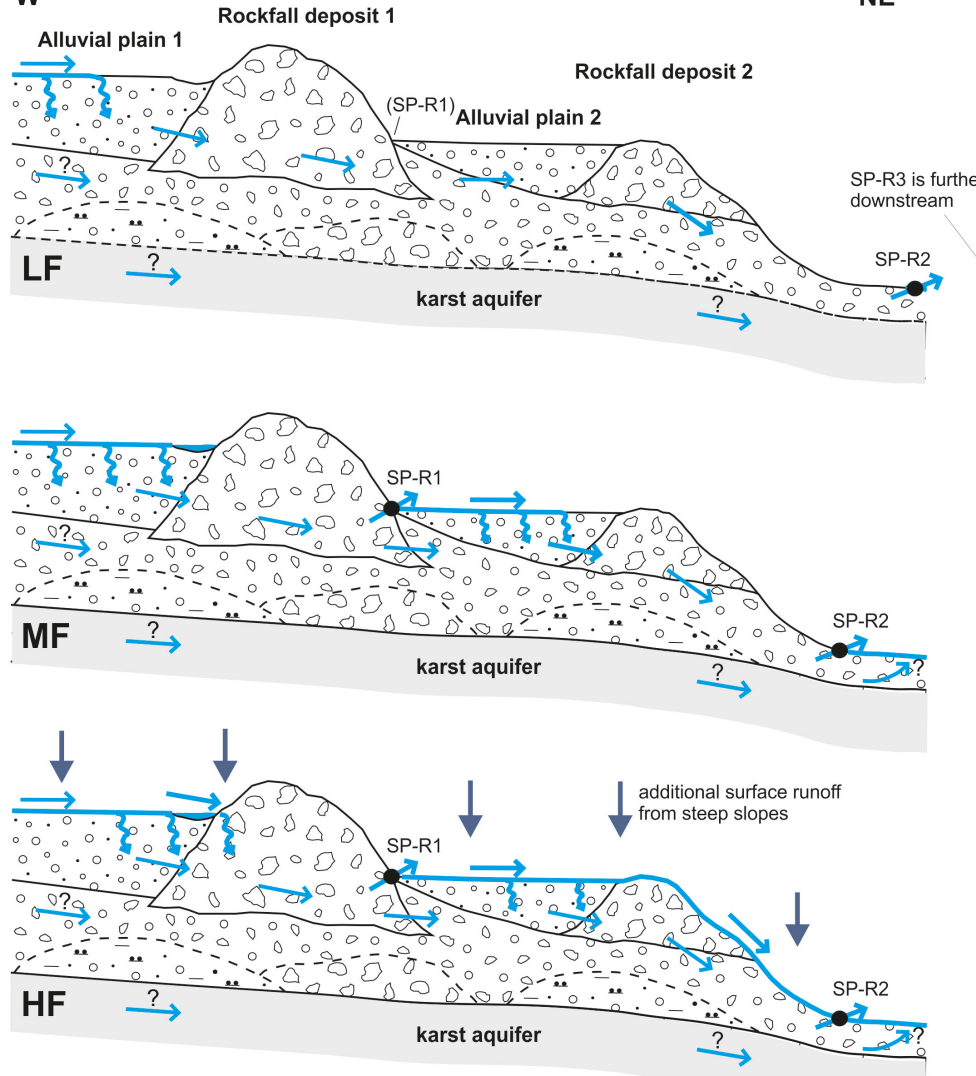

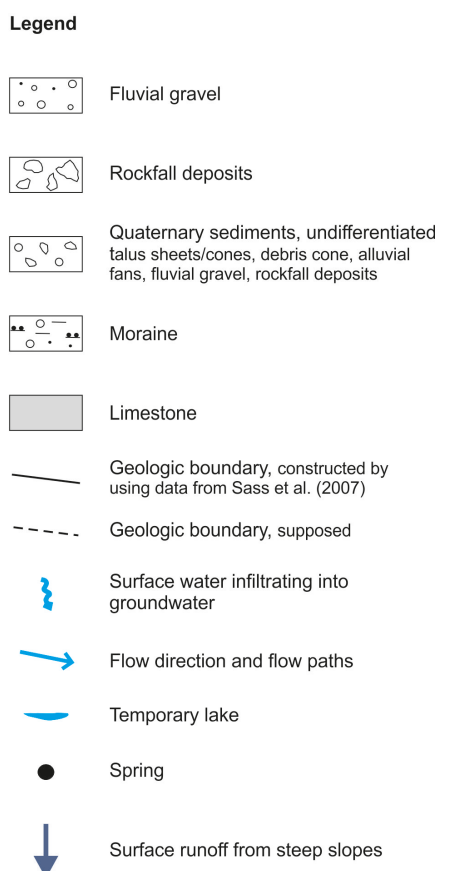

Figure 6. Conceptual model of surface and groundwater flow in the series of alluvial/rockfall aquifers of the Reintal under low-, moderate-, and high-flow conditions (LF, MF, and HF, respectively. The tracer injection in 2011 was done under high-flow conditions. The length of the section is $1.5 \mathrm{~km}$ and is vertically exaggerated.

flow path, and drains underground to spring SP-R2 (Fig. 6). Because the water level is higher than during low-flow conditions, spring SP-R2 discharges directly downstream from the alluvial/rockfall deposits. During moderate-flow conditions, the steep slopes along the valley contribute a few tens of $\mathrm{Ls}^{-1}$ to surface runoff, which is only a small proportion of total stream flow.

High-flow conditions occur after intense or prolonged precipitation events and during peak snowmelt in early summer. Because the water table is high, a substantial proportion of the groundwater discharges directly downstream from the first alluvial/rockfall deposits at spring SP-R1, where discharge can exceed $1 \mathrm{~m}^{3} \mathrm{~s}^{-1}$. While some of the water infiltrates the second alluvial/rockfall aquifer, there is also surface flow over the second alluvial/rockfall deposits (Fig. 6). Surface flow and subsurface drainage converge and mix at spring SP-R2. After large precipitation events, fast-flowing streams and torrents from steep slopes along the valley deliver surface runoff. Most high-flow conditions have been observed when peak discharge rates exceed $2.3 \pm 0.2 \mathrm{~m}^{3} \mathrm{~s}^{-1}$ at site GS-RD.
Table 1. Results of the 2011 tracer test in the Reintal.

\begin{tabular}{lllll}
\hline & & SP-R1 & SP-R2 & SP-R3 \\
\hline Linear distance & $\mathrm{m}$ & 500 & 1500 & 3150 \\
Mean discharge* & $\mathrm{L} \mathrm{s}^{-1}$ & 440 & 580 & 2500 \\
First detection & $\mathrm{h}$ & 8.4 & 23.0 & 22.5 \\
Max. flow velocity & $\mathrm{m} \mathrm{h}^{-1}$ & 59.7 & 65.2 & 140 \\
Peak transit time (1st peak) & $\mathrm{h}^{-1}$ & 16.3 & 28.4 & 65.8 \\
Peak flow velocity (1st) & $\mathrm{m} \mathrm{h}^{-1}$ & 30.6 & 52.8 & 47.8 \\
Max. concentration (1st) & $\mathrm{\mu g} \mathrm{L}^{-1}$ & 52.1 & 21.8 & 4.1 \\
Peak transit time (2nd peak) & $\mathrm{h}^{-1}$ & - & 116.8 & 262.2 \\
Peak flow velocity (2nd) & $\mathrm{m} \mathrm{h}^{-1}$ & - & 12.8 & 12.0 \\
Concentration (2nd) & $\mu \mathrm{g} \mathrm{L}^{-1}$ & - & 1.5 & 0.3 \\
Recovery & $\%$ & 30.0 & 20.5 & 58.7 \\
Water volume & $\mathrm{m}^{3}$ & 25883 & - & - \\
\hline Mean transit time (1st peak) & $\mathrm{h}^{-1}$ & 21.3 & 33.7 & 85.6 \\
Mean flow velocity (1st) & $\mathrm{m} \mathrm{h}^{-1}$ & 23.5 & 44.5 & 36.8 \\
Dispersion (1st) & $\mathrm{m}^{2} \mathrm{~h}^{-1}$ & 630 & 806 & 15700 \\
$R^{2}$ & - & 0.966 & 0.945 & 0.916 \\
\hline
\end{tabular}

* Mean discharge during main tracer breakthrough. 


\subsection{Drainage properties}

The overall results of the tracer test enabled insights into drainage properties of different parts of the alluvial/rockfall system and proportions of flow paths to the total discharge along the valley. The naphthionate was detected at all three sampling points: the two springs SP-R1 and SP-R2 and the outlet of the aquifer system SP-R3 (Fig. 4, Table 1). Highflow conditions occurred during the first 3 days after the injection (Fig. 6).

The tracer breakthrough curve (BTC) at SP-R1, $500 \mathrm{~m}$ downgradient from the injection site, has one clear peak and a short tail (Fig. 7a). The tracer was first observed $8 \mathrm{~h}$ after the injection, and the tracer peak concentration of $52.1 \mu \mathrm{g} \mathrm{L}^{-1}$ was measured $16 \mathrm{~h}$ after the injection. The linear peak flow velocity was about $31 \mathrm{~m} \mathrm{~h}^{-1}$. A discharge of $440 \mathrm{~L} \mathrm{~s}^{-1}$ was measured during the first 3 days, resulting in recovery of $30 \%$ of the tracer.

At spring SP-R2, the tracer was first detected after $23 \mathrm{~h}$ (Fig. 7b), and the tracer peak concentration of $21.8 \mu \mathrm{g} \mathrm{L}^{-1}$ was measured $28 \mathrm{~h}$ after injection. The linear peak flow velocity was $53 \mathrm{~m} \mathrm{~h}^{-1}$. During the first $75 \mathrm{~h}$, the BTC had one sharp peak followed by a decrease of concentration down to $0.6 \mu \mathrm{g} \mathrm{L}^{-1}$. $117 \mathrm{~h}$ after injection, the concentration rose slightly to $1.5 \mu \mathrm{g} \mathrm{L}^{-1}$, forming a second, small peak (Fig. 7b, Table 1). During the first half of the tracer breakthrough (about the first $75 \mathrm{~h}$ ), flow conditions were high and surface flow occurred downstream from SP-R1 (Fig. 6). The main peak of the breakthrough curve at SP-R2 is therefore mostly related to surface flow from SP-R1. However, after $75 \mathrm{~h}$, moderate-flow conditions were reached and all water from SP-R1 infiltrated (Fig. 6). We therefore interpret the second increase in tracer concentration as a separate peak related to peak concentrations in subsurface flow. The measured concentration of $1.5 \mu \mathrm{g} \mathrm{L}^{-1}$ is 2 to 3 times greater than the values measured before $\left(0.56 \mu \mathrm{g} \mathrm{L}^{-1}\right)$ and after $\left(0.78 \mu \mathrm{g} \mathrm{L}^{-1}\right)$ the peak and thus larger than the measurement error. The natural fluorescent background values of the sample were as low as the values of the samples before and after the second peak so that influence by organic matter content and turbidity can be excluded. Equally, we exclude remobilization of the tracer after smaller precipitation events because discharge at the gauging stations decreased gradually. Assuming that the second peak is related to subsurface flow, the linear subsurface flow velocity was $13 \mathrm{~m} \mathrm{~h}^{-1}$ and thus substantially less than the linear surface-flow velocity of $53 \mathrm{~m} \mathrm{~h}^{-1}$. During the main part of the tracer breakthrough, mean discharge at this sampling point was about $580 \mathrm{~L} \mathrm{~s}^{-1}$, and tracer recovery was about $21 \%$.

At site SP-R3, the outlet of the system, the maximum tracer concentrations of $4 \mu \mathrm{g} \mathrm{L}^{-1}$ was measured $66 \mathrm{~h}$ after injection (Fig. 7c). The linear peak flow velocity was $48 \mathrm{~m} \mathrm{~h}^{-1}$. The shape of the tail at SP-R3 indicates the presence of the second peak at this site as well (Fig. 7c). Because of high dilution and high dispersion along the surface flow path, the
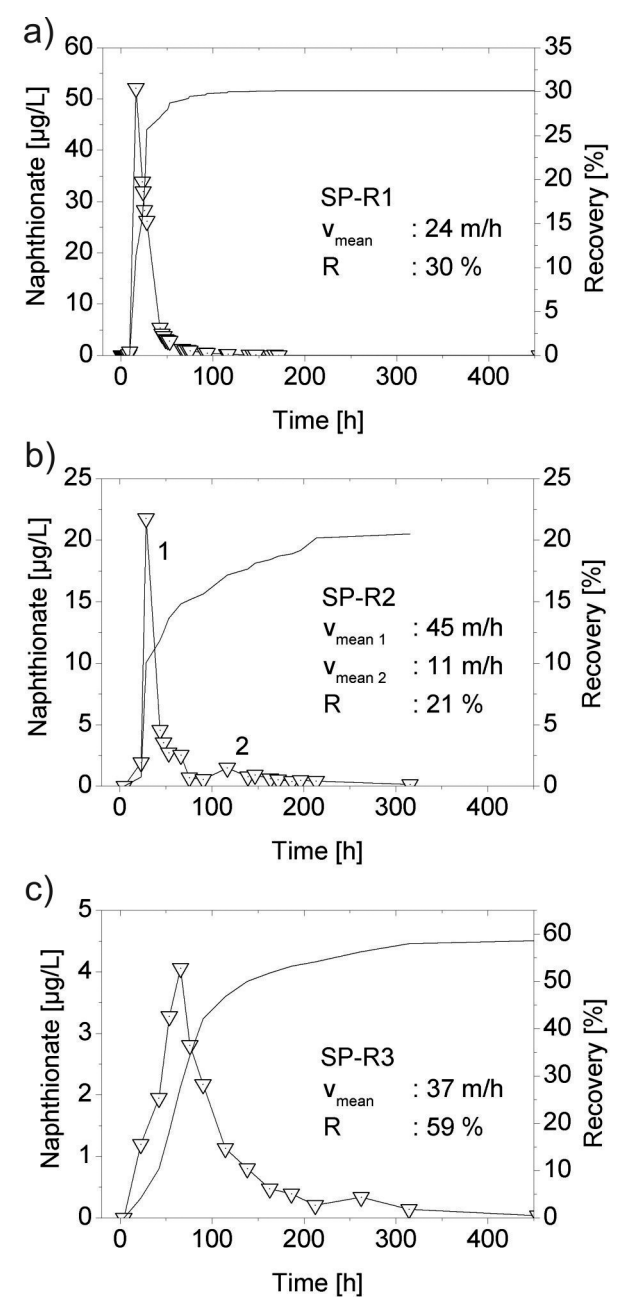

Figure 7. Naphthionate breakthrough curves at sampling points SPR1 (a), SP-R2 (b), and SP-R3 (c) in the Reintal. Sampling points were located in the river bed and show dispersion of the tracer downstream the injection point. Total recovery was measured at the outlet of the system at SP-R3.

second peak is small but recognizable. The sampling point is about $3.1 \mathrm{~km}$ from the injection point. The mean discharge at this site was about $2500 \mathrm{~L} \mathrm{~s}^{-1}$, and tracer recovery was $59 \%$.

Hydraulic parameters of the system were determined by ADM modeling of the observed BTCs at the observation points. A dispersion of $630 \mathrm{~m}^{2} \mathrm{~h}^{-1}$ was obtained from data for spring SP-R1 and applies to flow through the highpermeability part of the rockfall aquifer. Results from sites SP-R2 and SP-R3 are influenced by surface flow and are not discussed further. However, high dispersion values for site SP-R3 indicate highly turbulent flow of the stream.

The flow velocities obtained are attributed to different parts within the aquifer system, and tracer recovery demonstrates discharge proportions of flow paths. The flow velocities of $30 \mathrm{~m} \mathrm{~h}^{-1}$ along the short flow path from IP-2011 to SP-R1 are very high for a porous aquifer and are attributable 

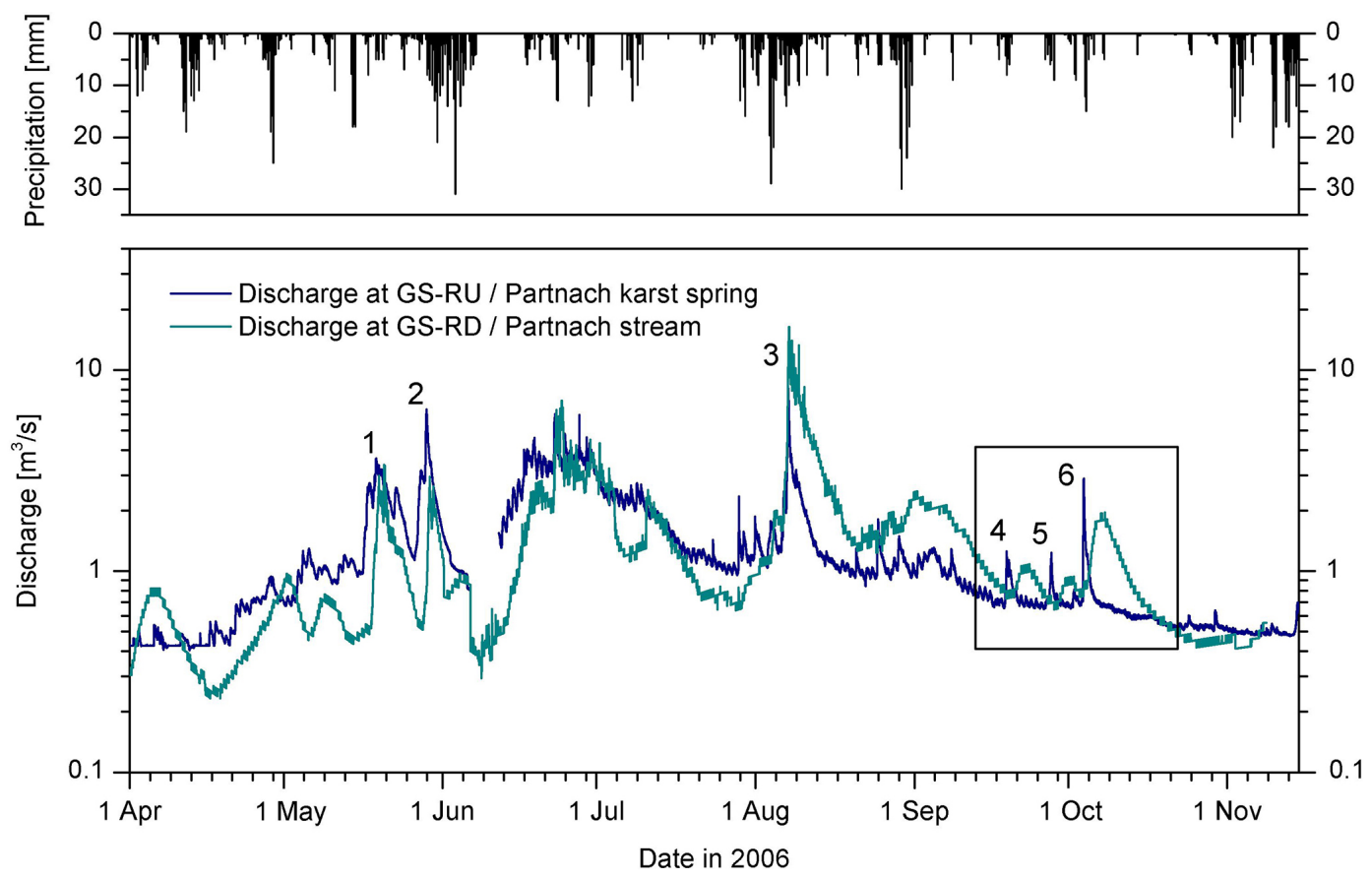

Figure 8. Hydrographs at the upstream (Partnach karst spring, site GS-RU) and downstream (Partnach stream, site GS-RD) gauging stations in the Reintal in 2006. Precipitation data (6 h time step) was obtained from the weather station at the Zugspitze (DWD).

to water flowing through coarse-grained rockfall deposits with numerous large limestone blocks. Even higher flow velocities of 65 to $81 \mathrm{~m} \mathrm{~h}^{-1}$ were measured by a tracer test in an alpine rockfall deposit (Schwarzwasser valley, Austria) and attributed to mechanical and dissolutional enlarged flow paths through large limestone blocks (Sinreich et al., 2002). The tracer recovery of $30 \%$ at site SP-R1 indicates that only about $1 / 3$ of spring infiltration discharges directly downgradient from the first alluvial/rockfall deposits. Along the long subsurface flow path to SP-R2, substantially lower flow velocities of $13 \mathrm{~m} \mathrm{~h}^{-1}$ occur because flow passes through alluvial gravel. The decreased recovery of $21 \%$ at SP-R2 in comparison with recovery at SP-R1 is related to infiltration processes upstream at the alluvial/rockfall aquifer under moderate- to high-flow conditions (Fig. 6). The total recovery of the tracer downstream at SP-R3 reaches $59 \%$ because stream discharge increases steadily in a downstream direction to the outlet and there are further inflows from the Quaternary sediments into the stream. The tracer test thus demonstrated that there is a large amount of water draining underground.

The total tracer recovery of $59 \%$ is well documented with samples collected during the main breakthrough at SP-R3 and continuous discharge measurements at GS-RD. As all of the water from the upper valley drains towards SP-R3, a high recovery was assumed. The unrecovered tracer might be attributable to microbial or photo decay, but might also be stored in the alluvial/rockfall aquifers. Storage of groundwater in the alluvial/rockfall system is also indicated by discharge analysis (Sect. 4.3). In that case, a difference of about $41 \%$ would indicate a relatively large storage capacity of the series of Alpine alluvial/rockfall aquifers.

\subsection{Discharge characteristics}

The hydrographs in the Reintal show distinct annual patterns because of the snowmelt-controlled discharge regime. In 2006, discharge begins to increase in mid-April and reaches a characteristic discharge maximum of about $7 \mathrm{~m}^{3} \mathrm{~s}^{-1}$ at the end of June, corresponding to the period of maximum snowmelt (Fig. 8). Daily discharge fluctuations of about $100 \mathrm{~L} \mathrm{~s}^{-1}$ are attributed to diurnal temperature changes and meltwater production from the glacier and snow fields (Figs. 8 and S1 in the Supplement). There are several discharge peaks related to moderate to large precipitation events. Maximum discharge rates of $8 \mathrm{~m}^{3} \mathrm{~s}^{-1}$ at GS-RU and $16 \mathrm{~m}^{3} \mathrm{~s}^{-1}$ at GS-RD were measured after an extreme precipitation event in 2006. With decreasing snowmelt contribution, discharge decreased gradually to $0.5 \mathrm{~m}^{3} \mathrm{~s}^{-1}$ during the second half of 2006 and 2011. As the valley is largely inaccessible during winter months, there has been only one observation (March 2007) that the karst spring is not perennial. The stream at the outlet of the system (site GS-RD) has not been observed to run dry during winter months.

Hydrologic flow conditions and water levels in the alluvial/rockfall aquifer have a substantial influence on discharge characteristics in the valley. Differences between the hydrographs upstream and downstream from the alluvial/rockfall 


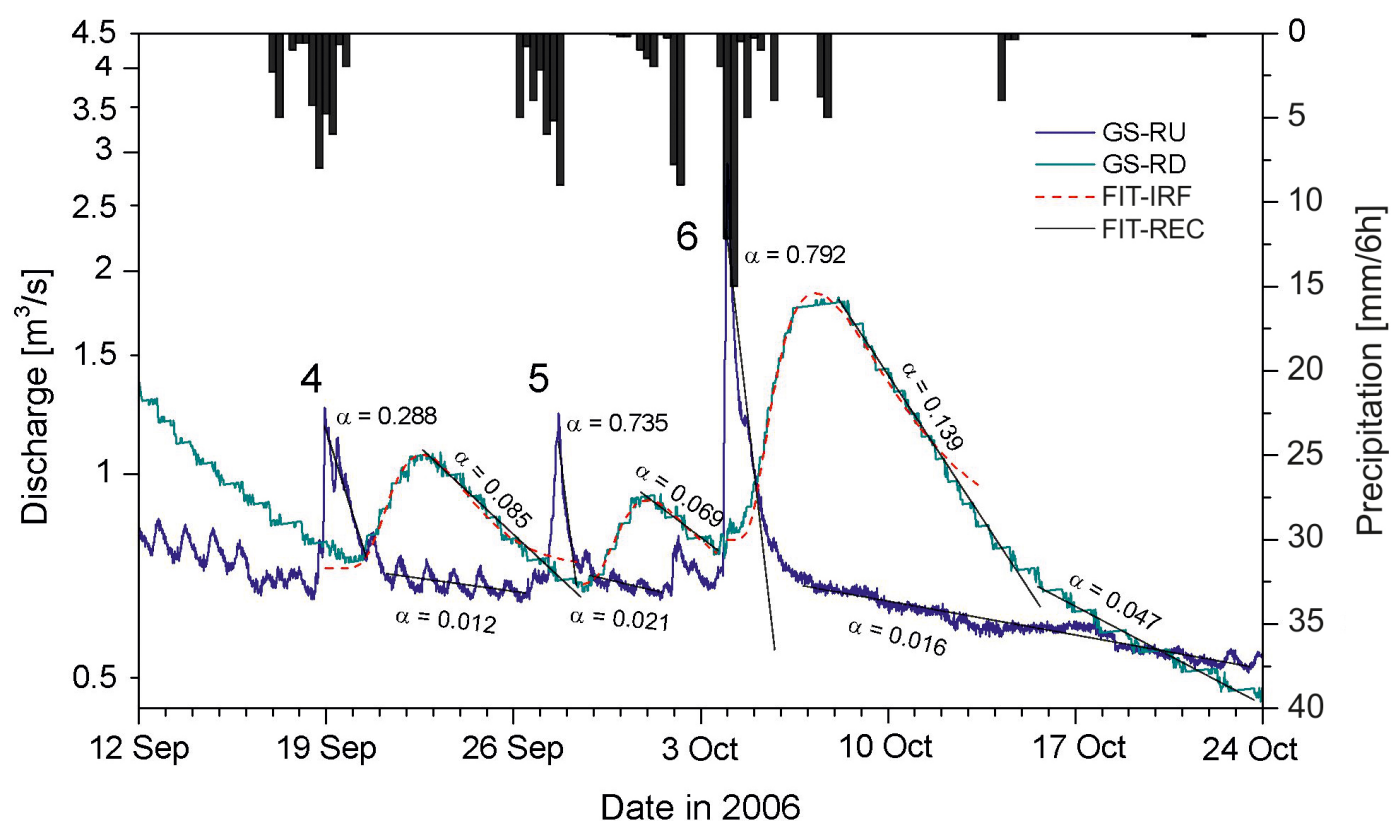

Figure 9. Discharge characteristics in late summer and autumn of 2006 in the Reintal demonstrating damping effects of the series of alpine alluvial/rockfall deposits. GS-RU: discharge from the karst spring upstream the alluvial/rockfall aquifer; GS-RD: discharge downstream at the outlet of the aquifer system; FIT-IRF: fit of impulse-response function; and FIT-REC: fit of recession analysis.

aquifers depend on surface and subsurface drainage between the two sites. The input signal at the karst spring shows that sharp discharge peaks occur less than $6 \mathrm{~h}$ following precipitation events, reflecting concentrated drainage and pressurized flow through a well-developed karst system. In summer (May-August), the sharp input signal at site GS-RU results in rapid and marked discharge responses downstream from the alluvial/rockfall aquifer systems (site GS-RD) (peaks 1-3 and peaks 7-9, Figs. 8 and S1). Short lag times of a few hours are associated with precipitation events occurring at high water levels, when subsurface flow paths are short and surface discharge downstream from the upgradient rockfall deposits results in rapid transit of the flood wave (Figs. 6 and 8). Piston flow effects in the saturated alluvial/rockfall aquifer further accelerate the process. An extremely fast response time of less than $5 \mathrm{~h}$ also can be attributed to surface runoff and torrents from steep slopes along the valley (Fig. 6).

Recharge events occurring during low-flow conditions result in distinctive wide discharge peaks downstream from the alluvial/rockfall deposits. In spring and autumn, sharp discharge peaks upstream cause delayed flood waves downstream that span several days (peaks 4-6 and 10-11, Figs. 8, 9, and S1). The mean lag time between maximum discharge at the karst spring (GS-RU) and the outlet of the alluvial/rockfall aquifer (GS-RD) determined by fitting the impulse-response function (Eq. 3) is $101 \mathrm{~h}$ (Table 3). Substantial flood damping is indicated by a decrease in maximum discharge of a factor of 1.5 as the average of three responses (Fig. 9). The strong damping effects are attributable to infiltration associated with low water levels, resulting in a long subsurface flow path of up to $2 \mathrm{~km}$ and storage within the aquifer (Fig. 6). During prolonged periods of low-flow conditions, e.g., during dry periods or in late autumn, flow velocities are expected to decrease as groundwater levels fall and discharge decreases. Lag times determined from the hydrographs can increase to values as high as $190 \mathrm{~h}$ in extreme dry years, e.g., 2003 (Table S3). On the basis of 38 discharge events that occurred during 2002-2011, lag times of about 5, 35 , and $101 \mathrm{~h}$ between the input at GS-RU and output signal at GS-RD are dominant (Fig. 10 and Tables 2 and S3). While there is no direct correlation between lag times and individual hydrometeorlogical parameters (Fig. S2), lag times are related to the hydrologic flow conditions in the alluvial/rockfall aquifer system.

The discharge ratio downstream from the alluvial/rockfall aquifers is less than that of the Partnach spring, indicating flow damping along the subsurface flow path between the two sites. While the discharge ratio at GS-RU has a mean value of 2.7, the ratio downstream from the aquifer system at site GS-RD has a mean value of only 1.9 (Fig. 11a, Table 2). The mean values exclude the extreme event in $\mathrm{Au}-$ gust 2006, which resulted in discharge ratios of 8 at GSRU and 22 at GS-RD. A substantially higher discharge ratio downstream at GS-RD is the result of a high proportion of surface runoff relative to groundwater discharge. Extreme precipitation intensity followed by a high volume of surface runoff likely causes this discharge response. Nevertheless, the discharge ratio for the Reintal is much less than that for other Alpine catchments, e.g., the Lahnenwiesgraben, where a ratio of up to 2500 was reported by Schmidt and 
Table 2. Discharge characteristics of selected precipitation events in 2006 and 2011 . All events with a peak discharge $Q_{\mathrm{P}}>2.3 \pm 0.2 \mathrm{~m}^{3} \mathrm{~s}^{-1}$ are high-flow events. $Q_{\mathrm{i}}$ : initial discharge; $Q_{\mathrm{P}}$ : peak discharge; discharge response: ratio between direct discharge $\left(Q_{\mathrm{P}}-Q_{\mathrm{i}}\right)$ and precipitation, conversion factor, and catchment area $\left(P_{\mathrm{peak}} \cdot f_{\mathrm{c}} \cdot A\right)$; discharge ratio: quotient between $Q_{\mathrm{P}}$ and $Q_{\mathrm{i}}$; lag time: time difference between discharge peak upstream (GS-RU) and downstream (GS-RD) from the rockfall aquifers; flow conditions indicate high-flow (HF) and low-to-moderate-flow conditions (LF/MF) of the individual events.

\begin{tabular}{|c|c|c|c|c|c|c|c|c|c|}
\hline Event & $\begin{array}{c}\text { Gauging } \\
\text { station }\end{array}$ & $P_{\mathrm{SUM}}^{\mathrm{a}}$ & $\begin{array}{c}\text { Peak } \\
\text { rainfall } \\
\text { in } 6 \mathrm{~h}^{\mathrm{b}}\end{array}$ & $Q_{\mathrm{i}}$ & $Q_{\mathrm{P}}$ & $\begin{array}{c}\text { Discharge } \\
\text { response }\end{array}$ & $\begin{array}{r}\text { Discharge } \\
\text { ratio }\end{array}$ & $\begin{array}{l}\text { Lag } \\
\text { time }\end{array}$ & $\begin{array}{c}\text { Flow } \\
\text { conditions } \mathrm{d}\end{array}$ \\
\hline- & - & $\mathrm{mm}$ & $\mathrm{mm}$ & $\mathrm{m}^{3} \mathrm{~s}^{-1}$ & $\mathrm{~m}^{3} \mathrm{~s}^{-1}$ & - & - & $\mathrm{h}$ & - \\
\hline 20 May 2006 & $\begin{array}{l}\text { GS-RU } \\
\text { GS-RD }\end{array}$ & 9 & 5 & $\begin{array}{l}0.97 \\
0.53\end{array}$ & $\begin{array}{l}3.52 \\
3.11\end{array}$ & $\begin{array}{l}1.338 \\
0.481\end{array}$ & $\begin{array}{l}3.63 \\
5.87\end{array}$ & 38 & $\mathrm{HF}$ \\
\hline 28 May 2006 & $\begin{array}{l}\text { GS-RU } \\
\text { GS-RD }\end{array}$ & 15 & 8 & $\begin{array}{l}1.14 \\
0.51\end{array}$ & $\begin{array}{l}6.03 \\
2.63\end{array}$ & $\begin{array}{l}1.432 \\
0.254\end{array}$ & $\begin{array}{l}5.29 \\
5.16\end{array}$ & 33 & $\mathrm{HF}$ \\
\hline 7 Aug 2006 & $\begin{array}{l}\text { GS-RU } \\
\text { GS-RD }\end{array}$ & 49 & 10 & $\begin{array}{l}0.96 \\
0.64\end{array}$ & $\begin{array}{c}8.09 \\
14.40\end{array}$ & $\begin{array}{l}1.537 \\
1.114\end{array}$ & $\begin{array}{r}8.43 \\
22.50\end{array}$ & 3.8 & $\mathrm{HF}$ \\
\hline 18 Sep 2006 & $\begin{array}{l}\text { GS-RU } \\
\text { GS-RD }\end{array}$ & 17 & 8 & $\begin{array}{l}0.65 \\
0.74\end{array}$ & $\begin{array}{l}1.25 \\
1.06\end{array}$ & $\begin{array}{l}0.297 \\
0.103\end{array}$ & $\begin{array}{l}1.92 \\
1.43\end{array}$ & $101^{\mathrm{c}}$ & $\mathrm{LF}$ \\
\hline 27 Sep 2006 & $\begin{array}{l}\text { GS-RU } \\
\text { GS-RD }\end{array}$ & 26 & 9 & $\begin{array}{l}0.65 \\
0.67\end{array}$ & $\begin{array}{l}1.22 \\
0.93\end{array}$ & $\begin{array}{l}0.258 \\
0.080\end{array}$ & $\begin{array}{l}1.88 \\
1.39\end{array}$ & $93^{c}$ & $\mathrm{LF}$ \\
\hline 4 Oct 2006 & $\begin{array}{l}\text { GS-RU } \\
\text { GS-RD }\end{array}$ & 29 & 15 & $\begin{array}{l}0.67 \\
0.77\end{array}$ & $\begin{array}{l}2.84 \\
1.80\end{array}$ & $\begin{array}{l}0.360 \\
0.093\end{array}$ & $\begin{array}{l}4.24 \\
2.34\end{array}$ & $106^{\mathrm{c}}$ & $\mathrm{LF}$ \\
\hline 18 Jun 2011 & $\begin{array}{l}\text { GS-RU } \\
\text { GS-RD }\end{array}$ & 39 & 20 & $\begin{array}{l}1.65 \\
2.58\end{array}$ & $\begin{array}{l}3.77 \\
4.96\end{array}$ & $\begin{array}{l}0.358 \\
0.192\end{array}$ & $\begin{array}{l}2.28 \\
1.92\end{array}$ & 9.5 & $\mathrm{HF}$ \\
\hline 30 Jun 2011 & $\begin{array}{l}\text { GS-RU } \\
\text { GS-RD }\end{array}$ & 30 & 16 & $\begin{array}{l}1.34 \\
2.04\end{array}$ & $\begin{array}{l}4.02 \\
3.08\end{array}$ & $\begin{array}{l}0.477 \\
0.149\end{array}$ & $\begin{array}{l}3.00 \\
1.51\end{array}$ & 29 & $\mathrm{HF}$ \\
\hline 7 Aug 2011 & $\begin{array}{l}\text { GS-RU } \\
\text { GS-RD }\end{array}$ & 55 & 31 & $\begin{array}{l}0.88 \\
2.00\end{array}$ & $\begin{array}{l}2.65 \\
3.45\end{array}$ & $\begin{array}{l}0.162 \\
0.086\end{array}$ & $\begin{array}{l}3.01 \\
1.73\end{array}$ & 36 & $\mathrm{HF}$ \\
\hline 5 Sep 2011 & $\begin{array}{l}\text { GS-RU } \\
\text { GS-RD }\end{array}$ & 52 & 21 & $\begin{array}{l}0.52 \\
1.04\end{array}$ & $\begin{array}{l}1.96 \\
1.71\end{array}$ & $\begin{array}{l}0.177 \\
0.063\end{array}$ & $\begin{array}{l}3.77 \\
1.64\end{array}$ & $86^{\mathrm{c}}$ & LF \\
\hline 18 Sep 2011 & $\begin{array}{l}\text { GS-RU } \\
\text { GS-RD }\end{array}$ & 19 & 15 & $\begin{array}{l}0.46 \\
1.00\end{array}$ & $\begin{array}{l}1.2 \\
1.6\end{array}$ & $\begin{array}{l}0.152 \\
0.083\end{array}$ & $\begin{array}{l}2.61 \\
1.60\end{array}$ & 105 & LF \\
\hline 10 Oct 2011 & $\begin{array}{l}\text { GS-RU } \\
\text { GS-RD }\end{array}$ & 30 & 12 & $\begin{array}{c}0.45 \\
0.9\end{array}$ & $\begin{array}{l}3.16 \\
2.87\end{array}$ & $\begin{array}{l}0.500 \\
0.185\end{array}$ & $\begin{array}{l}7.02 \\
3.19\end{array}$ & 34 & $\mathrm{HF}$ \\
\hline \multicolumn{3}{|c|}{ Mean values (excluding extreme event in 2006) } & $\begin{array}{l}\text { GS-RU } \\
\text { GS-RD }\end{array}$ & $\begin{array}{l}1.04 \\
1.80\end{array}$ & $\begin{array}{l}2.65 \\
3.22\end{array}$ & $\begin{array}{l}0.389 \\
0.188\end{array}$ & $\begin{array}{l}2.65 \\
1.93\end{array}$ & & \\
\hline
\end{tabular}

${ }^{\text {a }}$ Sum of precipitation until peak discharge at GS-RU. ${ }^{b}$ Note that maximum resolution of sum of precipitation is $6 \mathrm{~h} .{ }^{\mathrm{c}}$ Obtained by impulse-response analysis.

${ }^{d}$ predominant flow conditions: high-flow conditions (HF) and low-flow conditions (LF); mean-flow conditions (MF) are mainly a transition between LF to HF and therefore are not listed separately.

Morche (2006). The Lahnenwiesgraben catchment is largely covered by glacial sediment, and the bedrock is dominated by a diverse lithology, including marls and mudstones. Further examples of hydrographs showing annual flood peaks for different catchment areas in Austria are given by Gaál et al. (2012). Analyses indicate that, in addition to the geologic setting, other factors, such as climate and catchment properties, influence discharge characteristics and flood generation processes (Norbiato et al., 2009; Merz and Blöschl, 2009; Gaál et al., 2012).

The much larger recession coefficients upstream relative to downstream is evidence of the strong flood-buffering effects of the alluvial/rockfall deposits and demonstrates that they act as a natural retention zone. Analyses of 15 recession events demonstrate that flood recession coefficients at the karst spring (GS-RU) are generally about a factor of 2 to 5 higher than those downstream the alluvial/rockfall deposits 
Table 3. Results of the impulse-response analysis for three discharge events in 2006. $A_{\text {in }}$ : area under input signal at site GS-RU; $A_{\text {out }}$ : area under output signal at site GS-RD; $t_{\mathrm{m}}$ : mean transit time; $\omega$ : variance of time; $R^{2}$ : coefficient of determination from impulseresponse function.

\begin{tabular}{lrrrcc}
\hline Date & $A_{\text {in }}$ & $A_{\text {out }}$ & $t_{\mathrm{m}}$ & $\omega$ & $R^{2}$ \\
\hline 20 Sep 2006 & 10.7 & 30.5 & 100.7 & 0.379 & 0.915 \\
28 Sep 2006 & 5.5 & 19.4 & 93.2 & 0.388 & 0.897 \\
3 Oct 2006 & 24.9 & 131.1 & 105.9 & 0.542 & 0.972 \\
\hline
\end{tabular}

(GS-RD) (Figs. 10 and 11b). One of the highest flood recession coefficient at the karst spring $\left(1.04 \mathrm{~d}^{-1}\right)$ was determined for the extreme precipitation event in August 2006 and is attributed to concentrated recharge and drainage through the karst conduit network. For the same event, the flood recession coefficient downstream at GS-RD was about $0.20 \mathrm{~d}^{-1}$, while the falling limb is gentler and the base of the peak downstream (site GS-RD) generally is broader than at the Partnach spring upstream (site GS-RU). Baseflow recession coefficients at the karst spring and downstream from the alluvial/rockfall aquifer show the lowest values of about $0.005 \mathrm{~d}^{-1}$ after a long period of 45 days in 2005 , at which time the discharge decreased to the lowest values measured $\left(0.56 \mathrm{~m}^{3} \mathrm{~s}^{-1}\right.$ at GS-RU and $0.84 \mathrm{~m}^{3} \mathrm{~s}^{-1}$ at GS-RD). Water storage properties of the alluvial/rockfall aquifer maintain baseflow and perennial discharge at the outlet. An example of an area without drainage through permeable bedrock, such as rockfall deposits, is the Lainbachtal in the German Alps. The steep area is dominated by moraine sediments with a low hydraulic permeability, resulting in a rapid discharge response and substantially higher flood recession coefficients in the range of 7.2 to $84 \mathrm{~d}^{-1}$ (Wetzel, 2003). Sinreich et al. (2002) reported recession coefficients in the range of 1.3 to $3.4 \mathrm{~d}^{-1}$ for an alpine rockfall deposit in the Schwarzwasser valley in Austria. Surface discharge from a non-karstic catchment area infiltrates the rockfall deposit, and the highly fluctuating discharge peaks are damped by the rockfall deposits. In contrast, the moderate flood-recession coefficients in the Reintal indicate stronger flood-buffering properties, which could be related to the retention capacity of the alluvial/rockfall aquifer but also to the glacier and the karst aquifer.

Infiltration and storage processes are related to water levels in the aquifer system and are highest at low water levels. During low-flow conditions, the flood buffering of recharge events plays an important role because of the high infiltration of water into the series of alluvial/rockfall deposits and because of long subsurface flow paths (Fig. 6). This is shown by the long lag times and the damped discharge ratio at GS-RD. Substantial infiltration was also observed during early summer 2006, when discharge downstream from the alluvial/rockfall aquifers (site GS-RD) was about $0.4 \mathrm{~m}^{3} \mathrm{~s}^{-1}$ lower than that upstream at the karst spring (site GS-RU)

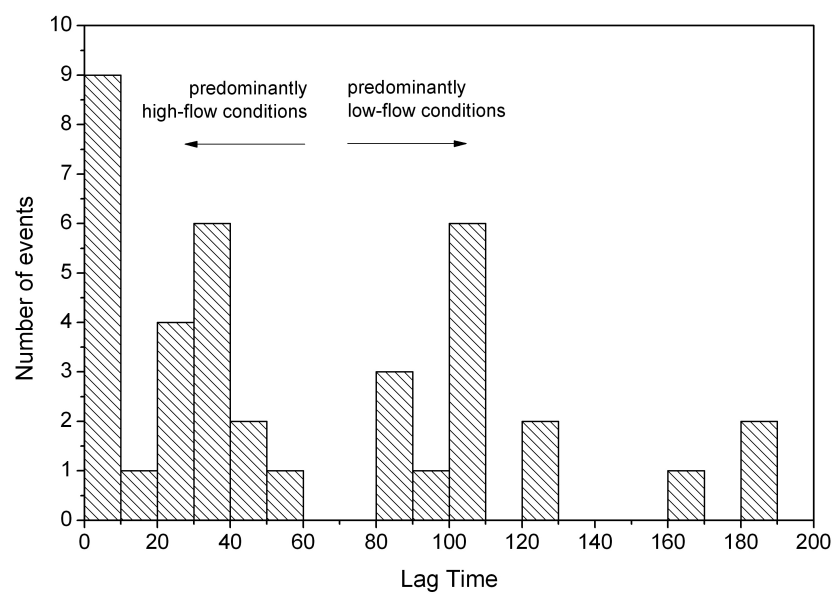

Figure 10. Lag times (in hours) between discharge peaks upstream (GS-RU) and downstream (GS-RD) from the alluvial/rockfall aquifer system, obtained from 38 discharge peaks during 20022011. Transit times of $<60 \mathrm{~h}$ are related to high-flow conditions (HF), while transit times of $>80 \mathrm{~h}$ are attributable to low-flow conditions (LF). Mean-flow conditions (MF) represent the transition from LF to HF and therefore are not shown explicitly.

(Fig. 8). The observations in 2006 indicate replenishment of the aquifer after low-flow conditions during the winter. At high water levels, when infiltration and subsurface flow paths are shortest, flood-buffering effects are at a minimum because of the high proportion of overland flow. This is indicated by the rapid transit of the flood wave but, nevertheless, moderate flood recession (Fig. 9). Even under high-flow conditions, flood recession is less than $0.2 \mathrm{~d}^{-1}$ and thus much smaller than for the karst system.

In conclusion, the alluvial/rockfall deposits have a large influence on the overall discharge of the high alpine karstic catchment area. Discharge ratios and their distribution of values are much smaller for the alluvial/rockfall aquifer than for the karst aquifer, except for the extreme event in 2005 (Figs. 6 and 11a). Similarly, flood recession coefficients are much smaller for the alluvial/rockfall aquifer (Figs. 6 and $11 \mathrm{~b}$ ). While the discharge response in the karst aquifer occurs very rapidly - within $6 \mathrm{~h}$ of the precipitation event - the peak discharge downstream from the alluvial/rockfall aquifer occurs after a great range of lag times, between 5,35 , and $101 \mathrm{~h}$ (Figs. 6 and 10). The observed flood-buffering potential in the Reintal therefore is related to the underground drainage properties and the water storage capacity of the permeable alluvial/rockfall deposits, which are natural retention zones.

High-magnitude rockfall deposits (bergsturz, rockslides) have a persistent and large impact on sediment transfer and ecosystems in high mountain basins. The interaction between surface and subsurface flow inhibits large sediment output in the catchment; sediment deposition occurs in the alluvial plains (Schmidt and Morche, 2006; Morche et al., 2007). 

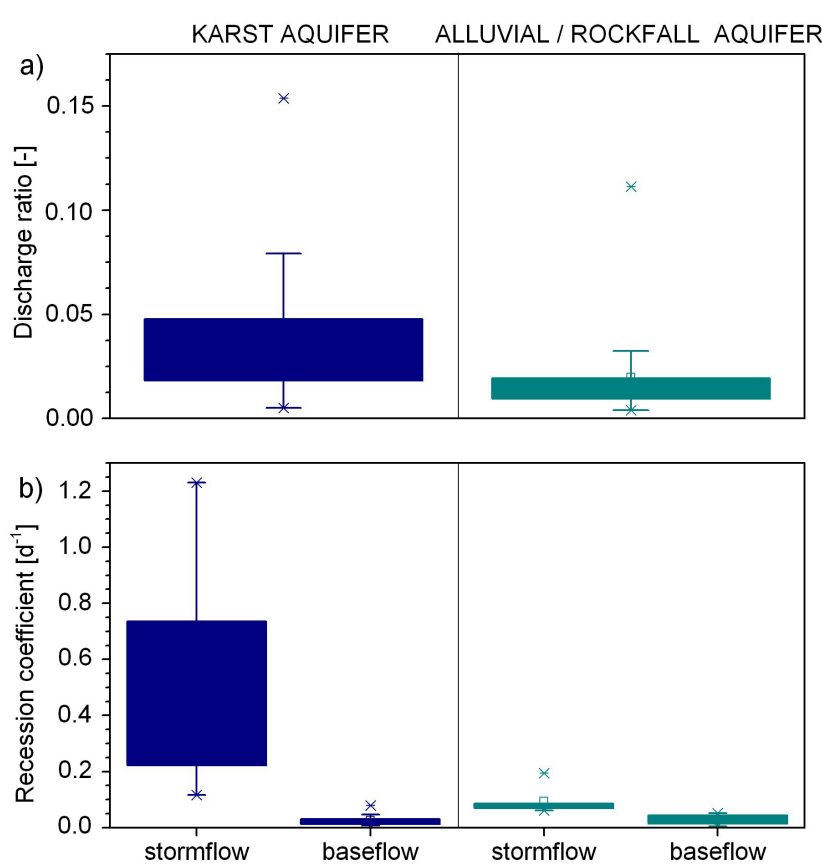

Figure 11. Discharge ratios (a) and recession coefficients (b) of the karst aquifer and the alluvial/rockfall aquifer in the Reintal.

Braided river systems on the alluvial plains and infiltration and storage in the alluvial/rockfall aquifer system enable the development of unique Alpine ecosystems in the Reintal. Because the flood-buffering properties of the aquifer system prevent abrasive fluvial erosion, vegetation can grow close to the stream bed.

\section{Conclusions and outlook}

The alluvial/rockfall aquifer system of the Reintal has a substantial influence on the discharge and water storage in the high alpine valley. The valley is characterized by a series of karst and alluvial/rockfall aquifers that affect discharge from the Alpine catchment. Depending on the hydrologic flow conditions, the surface and underground flow patterns change substantially in the valley. Under high-flow conditions, discharge peaks at the outlet of the valley occurred about $5 \mathrm{~h}$ after discharge peaks in the upper part of the valley. Because of high water levels, subsurface flow paths along the valley are short, and subsurface flow velocities of $30 \mathrm{~m} \mathrm{~h}^{-1}$ dominated in the coarse-grained rockfall deposits. Flood recession curves were substantially wider downstream than upstream, indicating that the strong interaction of surface and subsurface flow along the alluvial/rockfall aquifer system buffers flood flow. The greatest flood-damping effects were observed in response to recharge events that occurred under low-flow conditions during the autumn. Because of low water levels, subsurface flow path lengths increased and water discharged only downstream from the alluvial/rockfall deposits. Flow velocities decreased to $13 \mathrm{~m} \mathrm{~h}^{-1}$ along the long subsurface flow path. After recharge events, dominant lag times of $101 \mathrm{~h}$ occurred together with a decrease in peak discharge by a factor of 1.5. The storage properties of the aquifer enable replenishment and a slow release of water and thus provide baseflow during periods of low flow.

Flood-buffering and storage effects in the Reintal are a result of the presence of three natural retention zones: the glacier, the karst aquifer, and the alluvial/rockfall aquifer. In comparison with catchment areas underlain by impermeable bedrock, concentrated drainage and short transit times through well-developed karst structures result in a moderate discharge ratio, moderate flood recession, and a short discharge response after precipitation events. Because of underground drainage and lower flow velocities through alluvial/rockfall deposits, discharge ratios and flood recession coefficients decreased substantially, and the discharge response occurred with a time lag of several hours downstream in the valley. Thus, the alluvial/rockfall aquifer is of great hydrogeologic importance for the discharge characteristics of the high alpine valley.

The presence of such natural retention zones might be important with regard to climate change, i.e., floods and droughts. Other high Alpine valleys might also have hydrogeologic settings conducive to flood damping and baseflow maintenance. Better understanding of the hydrogeology of Alpine headwaters could be a useful tool for improved water management and the development of risk maps.

\section{The Supplement related to this article is available online at doi:10.5194/hess-18-4437-2014-supplement.}

Acknowledgements. We acknowledge the support of Deutsche Forschungsgemeinschaft (DFG) and Open Access Publishing Fund of Karlsruhe Institute of Technology. The work of David Morche was funded by DFG (grant numbers SCHM 472/12-1-3, SCHM 472/15-1 and MO 2068/3-1). We thank Barbara Mahler for valuable comments and proofreading the manuscript, and Andy Long, Michael Sinreich and two anonymous reviewers for helpful suggestions which improved the manuscript.

The service charges for this open access publication have been covered by a Research Centre of the Helmholtz Association.

Edited by: S. Attinger 


\section{References}

Asmuth, J. R. and von Knotters, M.: Characterising groundwater dynamics based on a system identification approach, J. Hydrol., 296, 118-134, doi:10.1016/j.jhydrol.2004.03.015, 2004.

Auer, I., Böhm, R., Jurkovic, A., Lipa, W., Orlik, A., Potzmann, R., Schöner, W., Ungersböck, M., Matulla, C., Briffa, K., Jones, P., Efthymiadis, D., Brunetti, M., Nanni, T., Maugeri, M., Mercalli, L., Mestre, O., Moisselin, J.-M., Begert, M., MüllerWestermeier, G., Kveton, V., Bochnicek, O., Stastny, P., Lapin, M., Szalai, S., Szentimrey, T., Cegnar, T., Dolinar, M., GajicCapka, M., Zaninovic, K., Majstorovic, Z., and Nieplova, E.: HISTALP - historical instrumental climatological surface time series of the Greater Alpine Region, Int. J. Climatol., 27, 17-46, doi:10.1002/joc.1377, 2007.

Badoux, A., Witzig, J., Germann, P. F., Kienholz, H., Lüscher, P., Weingartner, R., and Hegg, C.: Investigations on the runoff generation at the profile and plot scales, Swiss Emmental, Hydrol. Process., 20, 377-394, doi:10.1002/hyp.6056, 2006.

Bailly-Comte, V., Martin, J. B., Jourde, H., Screaton, E. J., Pistre, S., and Langston, A.: Water exchange and pressure transfer between conduits and matrix and their influence on hydrodynamics of two karst aquifers with sinking streams, J. Hydrol., 386, 5566, doi:10.1016/j.jhydrol.2010.03.005, 2010.

Barnett, T. P., Adam, J. C., and Lettenmaier, D. P.: Potential impacts of a warming climate on water availability in snow-dominated regions, Nature, 438, 303-309, doi:10.1038/nature04141, 2005.

Beniston, M., Stoffel, M., and Hill, M.: Impacts of climatic change on water and natural hazards in the Alps: Can current water governance cope with future challenges? Examples from the European "ACQWA" project, Environ. Sci. Policy, 14, 734-743, doi:10.1016/j.envsci.2010.12.009, 2011.

Bichler, B., Reischer, M., Höfer-Öllinger, G., Zagler, G., Whlidal, S., and Spötl, C.: Hydrogeology of the Untersberg and the adjacent Salzburg basin (Interactions of karst and porous aquifers), Pangeo Austria 2012, Abstractband Geo Wissenschaft plus Praxis, Salzburg, p. 27, 2012.

Blume, T., Zehe, E., and Bronstert, A.: Rainfall runoff response, event-based runoff coefficients and hydrograph separation, Hydrolog. Sci. J., 52, 843-862, doi:10.1623/hysj.52.5.843, 2007.

Bogataj, L. K.: How will the Alps Respond to Climate Change? Scenarios for the Future of Alpine Water, in: The Water Balance of the Alps, Innsbruck University Press, Innsbruck, 43-51, 2007.

Bonacci, O.: Karst springs hydrographs as indicators of karst aquifers, Hydrolog. Sci. J., 38, 51-62, doi:10.1080/02626669309492639, 1993.

Field, M. S. and Nash, S. G.: Risk assessment methodology for karst aquifers, 1. Estimating karst conduit-flow parameters, Environ. Monit. Assess., 47, 1-21, 1997.

Finger, D., Hugentobler, A., Huss, M., Voinesco, A., Wernli, H., Fischer, D., Weber, E., Jeannin, P.-Y., Kauzlaric, M., Wirz, A., Vennemann, T., Hüsler, F., Schädler, B., and Weingartner, R.: Identification of glacial meltwater runoff in a karstic environment and its implication for present and future water availability, Hydrol. Earth Syst. Sci., 17, 3261-3277, doi:10.5194/hess-173261-2013, 2013.
Gaál, L., Szolgay, J., Kohnová, S., Parajka, J., Merz, R., Viglione, A., and Blöschl, G.: Flood timescales: Understanding the interplay of climate and catchment processes through comparative hydrology, Water Resour. Res., 48, W04511, doi:10.1029/2011WR011509, 2012.

Geyer, T., Birk, S., Liedl, R., and Sauter, M.: Quantification of temporal distribution of recharge in karst systems from spring hydrographs, J. Hydrol., 348, 452-463, doi:10.1016/j.jhydrol.2007.10.015, 2008.

Goldscheider, N.: Fold structure and underground drainage pattern in the alpine karst system Hochifen-Gottesacker, Eclogae Geol Helv., 98, 1-17, 2005.

Goldscheider, N.: Alpine Hydrogeologie, Grundwasser, 16, 1, doi:10.1007/s00767-010-0157-2, 2011.

Goldscheider, N. and Neukum, C.: Fold and fault control on the drainage pattern of a double-karst-aquifer system, Winterstaude, Austrian Alps, Acta Carsologica, 39, 173-186, 2010.

Gremaud, V., Goldscheider, N., Savoy, L., Favre, G., and Masson, H.: Geological structure, recharge processes and underground drainage of a glacierised karst aquifer system, Tsanfleuron-Sanetsch, Swiss Alps, Hydrogeol. J., 17, 18331848, doi:10.1007/s10040-009-0485-4, 2009.

Haeberli, W. and Beniston, M.: Climate change and its impacts on glaciers and permafrost in the Alps, Ambio, 27, 258-265, 1998.

Haga, H., Matsumoto, Y., Matsutani, J., Fujita, M., Nishida, K., and Sakamoto, Y.: Flow paths, rainfall properties, and antecedent soil moisture controlling lags to peak discharge in a granitic unchanneled catchment, Water Resour. Res., 41, W12410, doi:10.1029/2005WR004236, 2005.

Hoffmann, T. and Schrott, L.: Determining sediment thickness of talus slopes and valley fill deposits using seismic refraction a comparison of 2D interpretation tools, Z. Geomorph. N. F. Suppl.-Bd., 127, 71-87, 2003.

Käss, W.: Geohydrologische Markierungstechnik, Borntraeger, Stuttgart, 557 pp., 2004.

Leibundgut, Ch., Maloszewski, P., and Külls, Ch.: Tracers in Hydrology, Wiley-Blackwell Verlag, West Sussex, UK., 415 pp., 2009.

Long, A. J. and Mahler, B. J.: Prediction, time variance, and classification of hydraulic response to recharge in two karst aquifers, Hydrol. Earth Syst. Sci., 17, 281-294, doi:10.5194/hess-17-2812013, 2013.

Maloszewski, P., Stichler, W., Zuber, A., and Rank, D.: Identifying the flow systems in a karstic-fissured-porous aquifer, the Schneealpe, Austria, by modelling of environmental ${ }^{18} \mathrm{O}$ and ${ }^{3} \mathrm{H}$ isotopes, J. Hydrol., 256, 48-59, doi:10.1016/S00221694(01)00526-1, 2002.

Merz, R. and Blöschl, G.: A regional analysis of event runoff coefficients with respect to climate and catchment characteristics in Austria, Water Resour. Res., 45, W01405, doi:10.1029/2008WR007163, 2009.

Millares, A., Polo, M. J., and Losada, M. A.: The hydrological response of baseflow in fractured mountain areas, Hydrol. Earth Syst. Sci., 13, 1261-1271, doi:10.5194/hess-13-12612009, 2009.

Morche, D. and Schmidt, K.-H.: Particle size and particle shape analyses of unconsolidated material from sediment sources and sinks in a small Alpine catchment (Reintal, Bavarian Alps, Germany), Z. Geomorphol. N. F., Suppl.-Bd., 138, 67-80, 2005. 
Morche, D., Schmidt, K. H., Heckmann, T., and Haas, F.: Hydrology and geomorphic effects of a high-magnitude flood in an alpine river, Geogr. Ann. A, 89, 5-19, 2007.

Morche, D., Witzsche, M., and Schmidt, K. H.: Hydrogeomorphological characteristics and fluvial sediment transport of a high mountain river (Reintal Valley, Bavarian Alps, Germany), Z. Geomorphol., 52, 51-77, doi:10.1127/0372-8854/2008/0052S10051, 2008.

Mueller, M. H., Weingartner, R., and Alewell, C.: Importance of vegetation, topography and flow paths for water transit times of base flow in alpine headwater catchments, Hydrol. Earth Syst. Sci., 17, 1661-1679, doi:10.5194/hess-17-1661-2013, 2013.

Norbiato, D., Borga, M., Merz, R., Bloschl, G., and Carton, A.: Controls on event runoff coefficients in the eastern Italian Alps, J. Hydrol., 375, 312-325, doi:10.1016/j.jhydrol.2009.06.044, 2009.

Plan, L., Decker, K., Faber, R., Wagreich, M., and Grasemann, B.: Karst morphology and groundwater vulnerability of high alpine karst plateaus, Environ. Geol., 58, 285-297, doi:10.1007/s00254-008-1605-5, 2009.

Rappl, A., Wetzel, K.-F., Büttner, G., and Scholz, M.: Dye tracer investigations at the Partnach Spring (German Alps), Hydrogeol. Wasserbewirts., 54, 220-230, 2010.

Sass, O., Krautblatter, M., and Morche, D.: Rapid lake infill following major rockfall (bergsturz) events revealed by groundpenetrating radar (GPR) measurements, Reintal, German Alps, Holocene, 17, 965-976, doi:10.1177/0959683607082412, 2007.

Schmidt, K. H. and Morche, D.: Sediment output and effective discharge in two small high mountain catchments in the Bavarian Alps, Germany, Geomorphology, 80, 131-145, doi:10.1016/j.geomorph.2005.09.013, 2006.

Schrott, L., Götz, J., Geilhausen, M., and Morche, D.: Spatial and temporal variability of sediment transfer and storage in an Alpine basin (Bavarian Alps, Germany), Geogr. Helvetica, 61, 191-200, 2006.
Sinreich, S., Goldscheider, N., and Hötzl, H.: Hydrogeologie einer alpinen Bergsturzmasse (Schwarzwassertal, Vorarlberg), Beitr. Hydrogeol., 53, 5-20, 2002.

Toride, N., Leij, F., and van Genuchten, M.: The CXTFIT code (version 2.1) for estimating transport parameters from laboratory or field tracer experiments, Research Report No. 137, US Salinity Laboratory, Agricultural Research Service, US Department of Agriculture, Riverside, California, 119 pp., 1999.

Van Genuchten, M. Th., Šimůnek, J., Leij, F. J., Toride, N., and Šejna, M.: STANMOD: Model use, calibration and validation, Trans. ASABE, 55, 1353-1366, 2012.

Viviroli, D. and Weingartner, R.: Water towers - A global view on the hydrological importance of mountains, Adv. Glob. Change Res., 31, 15-20, doi:10.1007/978-1-4020-6748-8_2, 2008.

Wassmer, P., Schneider, J. L., Pollet, N., and Schmitter-Voirin, C.: Effects of the internal structure of a rock-avalanche dam on the drainage mechanism of its impoundment, Flims sturzstrom and Ilanz paleo-lake, Swiss Alps, Geomorphology, 61, 3-17, doi:10.1016/j.geomorph.2003.11.003, 2004.

Wetzel, K.-F.: Runoff production processes in small alpine catchments within the unconsolidated Pleistocene sediments of the Lainbach area (upper Bavaria), Hydrol. Process., 17, 2463-2483, doi:10.1002/hyp.1254, 2003.

Wetzel, K.-F.: On the hydrology of the Partnach area in the Wetterstein Mountains (Bavarian Alps), Erdkunde, 58, 172-186, 2004.

Zillgens, B., Merz, B., Kirnbauer, R., and Tilch, N.: Analysis of the runoff response of an alpine catchment at different scales, Hydrol. Earth Syst. Sci., 11, 1441-1454, doi:10.5194/hess-111441-2007, 2007. 